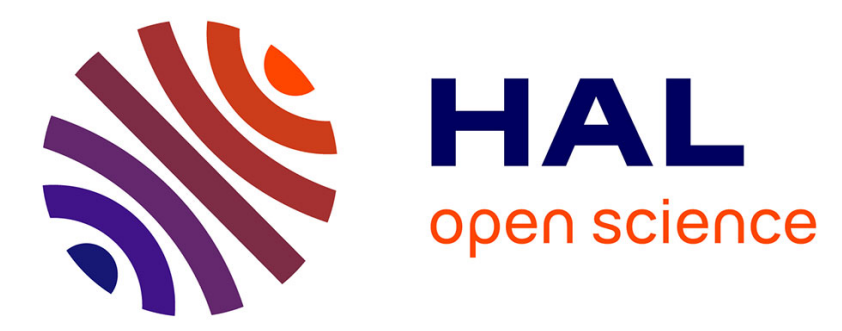

\title{
Star polymers with acid-labile diacetal-based cores synthesized by aqueous RAFT polymerization for intracellular DNA delivery
}

Thomas Gibson, Peter Smyth, M. Semsarilar, Aidan Mccann, William

Mcdaid, Michael Johnston, Christopher Scott, Efrosyni Themistou

\section{To cite this version:}

Thomas Gibson, Peter Smyth, M. Semsarilar, Aidan Mccann, William Mcdaid, et al.. Star polymers with acid-labile diacetal-based cores synthesized by aqueous RAFT polymerization for intracellular DNA delivery. Polymer Chemistry, 2020, 11 (2), pp.344-357. 10.1039/c9py00573k . hal-03005850

\section{HAL Id: hal-03005850 https://hal.science/hal-03005850}

Submitted on 15 Nov 2020

HAL is a multi-disciplinary open access archive for the deposit and dissemination of scientific research documents, whether they are published or not. The documents may come from teaching and research institutions in France or abroad, or from public or private research centers.
L'archive ouverte pluridisciplinaire HAL, est destinée au dépôt et à la diffusion de documents scientifiques de niveau recherche, publiés ou non, émanant des établissements d'enseignement et de recherche français ou étrangers, des laboratoires publics ou privés. 


\section{D) Check for updates}

Cite this: Polym. Chem., 2020, 11 344
Received 17th April 2019 Accepted 27th June 2019 DOI: 10.1039/c9py00573k rsc.li/polymers

\section{Star polymers with acid-labile diacetal-based cores synthesized by aqueous RAFT polymerization for intracellular DNA delivery $\dagger$}

\author{
Thomas J. Gibson, $\star^{\mathrm{a}}$ Peter Smyth, $\$^{\mathrm{b}}$ Mona Semsarilar, (D) Aidan P. McCann, ${ }^{\mathrm{b}}$ \\ William J. McDaid, ${ }^{\mathrm{b}}$ Michael C. Johnston, ${ }^{\mathrm{b}}$ Christopher J. Scott (D) ${ }^{\mathrm{b}}$ and \\ Efrosyni Themistou (D) *a
}

\begin{abstract}
The application of DNA-based therapeutics holds much potential, but it is limited by the ability to successfully deliver and transfect target cells. Here, acid-labile diacetal-based star polymers were synthesized by a facile 'arm-first' heterogeneous reversible addition-fragmentation chain transfer polymerization in biologically compatible solvents, for use as DNA delivery vehicles. Their cytotoxicity, DNA binding and transfection rates were evaluated. The star polymer arms are based on the biocompatible oligo(ethylene glycol) methacrylate (OEGMA) monomer, the cationic 2-(dimethylamino)ethyl methacrylate (DMAEMA) monomer and their mixtures. Their cores were prepared by the acid-labile diacetal bis[(2-methacryloyloxy)ethoxymethyl] ether (MOEME) or the non-degradable ethylene glycol dimethacrylate (EGDMA) cross-linker, for comparison. The MOEME-based star polymers showed accelerated degradation in acidic conditions. The fully cationic star polymers, PDMAEMA $26-\mathrm{MOEME}_{4}$-star and PDMAEMA $26-\mathrm{EGDMA}_{6}-$ star, showed higher cytotoxicity but also considerably better DNA complexation. The higher transfection efficiency obtained for PDMAEMA $26-\mathrm{MOEME}_{4}$-star (65.5\%) compared to PDMAEMA $26-E_{\text {EDMA }}$-star (44.2\%) can be attributed to the ability of the former to disassemble at endosomal $\mathrm{pH}$, due to its acidlabile MOEME-based core. The ability of the star polymer-DNA complexes to escape the endo/lysosomal pathway was shown to be a key determinant of transfection efficiency, as assessed by confocal microscopy and flow cytometry. In conclusion, these star polymers show promise as biocompatible, $\mathrm{pH}$ labile polymers for DNA delivery that can be synthesized without the need of toxic organic solvents.
\end{abstract} rscilpolymers

\section{Introduction}

The development of safe, non-toxic, efficient vehicles is crucial to the success of gene delivery. ${ }^{1,2}$ Although viral vectors for nucleic acid delivery entered clinical trials in the last few decades, concerns about their safety have limited their use. Polymeric nanocarriers, such as polycations, have attracted the interest of many researchers as good substitutes of viral vectors due to their lower immunogenicity and pathogenicity. $^{2,3}$

\footnotetext{
${ }^{a}$ School of Chemistry and Chemical Engineering, Queen's University Belfast, David Keir Building, Belfast BT9 5AG, UK. E-mail: e.themistou@qub.ac.uk ${ }^{b}$ Centre for Cancer Research \& Cell Biology, Queen's University Belfast, Belfast BT9 $7 A E$, UK

'Institut Européen des Membranes, IEM, UMR 5635, Université de Montpellier, ENSCM, CNRS, Montpellier, France

$\dagger$ Electronic supplementary information (ESI) available. See DOI: 10.1039/ c9py00573k

$\$$ These authors contributed equally.
}

Polycations, with their numerous positive charges, are capable of forming complexes with negatively charged molecules, such as DNA, through electrostatic interactions. ${ }^{4,5}$ Their ability to condense DNA has been known since the 1960s, when Olins et al. showed that mixing DNA with cationic polypeptides increased its stability against denaturation. ${ }^{5}$ Since cell membranes are inherently anionic or zwitterionic, uncomplexed DNA is unable to pass through the membrane into the cell. ${ }^{6}$ When bound to polycations however, the resulting complexes exhibit a partial positive or neutral charge that allow for easier uptake by the cell membrane. ${ }^{7}$ Recently, attention has been given to poly(2-(dimethylamino)ethyl methacrylate) (PDMAEMA) as a non-viral vector due to its buffering capacity and improved biocompatibility compared to the commonly used polyethylenimine (PEI). ${ }^{8}$ PDMAEMA polymers can be synthesized by reversible-deactivation radical polymerizations, ${ }^{9}$ such as reversible addition-fragmentation chain transfer (RAFT) polymerization, ${ }^{10,11}$ that allow the facile synthesis of tailor-made cationic polymers with complex structures, which are promising non-viral gene delivery vectors. ${ }^{12}$ In an effort to 
design better and more efficient cationic polymer vehicles for gene therapy, various methodologies are currently employed.

A common strategy used to increase solubility and biocompatibility of polycations is the incorporation of polyethylene glycol (PEG) groups into their structure. ${ }^{13,14}$ PEG-based polymers are neutral and they appear to have reduced cytotoxicity. They are also less likely to interact with blood proteins, resulting in enhanced biodistribution in the body. ${ }^{15}$ Rungsardthong et al. showed that mixing PEG with DMAEMA results in copolymers with increased solubility and superior DNA binding, but also lower transfection efficiency. ${ }^{16}$

Except from linear polycations, other macromolecular architectures are also studied for gene delivery. ${ }^{8,17}$ One of these architectures is star polymers, ${ }^{17}$ which are branched polymeric nanostructures consisting of multiple linear polymer chains, called "arms", tethered together at a central point, referred to as the "core". ${ }^{18,19}$ Star polymers with cationic polymer arms have distinct properties that are advantageous for use in DNA delivery applications. ${ }^{17,20}$ They exhibit better DNA binding than linear analogues, which is attributed to their unique star architecture. ${ }^{21-23}$ Since polymer molecular weight (MW) also has a considerable effect on polycation cytotoxicity, ${ }^{24}$ cationic star polymers that contain biodegradable cores may confer improved biocompatibility ${ }^{25}$ due to their ability to transform to lower MW products inside the body. Star polymers with cores that can break down in the acidic environment of the cell endosome, such as acetal-based cores, can also result in more efficient gene delivery. ${ }^{26-36}$

The most commonly used strategy for star polymer synthesis is the "arm-first" approach, which forms star polymers by cross-linking linear polymer chains. Star polymers prepared by this methodology appear to suffer from non-controllable broad arm number distributions, high dispersities $(\nexists \sim 2.0)$ determined by size exclusion chromatography (SEC), ${ }^{37,38}$ low yields due to incomplete arm to star conversions giving large amounts of unattached arms, and star-star coupling products. $^{39}$ All these are major issues in star polymer nanomedicine applications, highlighting the need for modifying this synthetic approach to a more efficient biologically-friendly methodology.

Both PEG-based monomers, such as oligo(ethylene glycol) methacrylate (OEGMA), ${ }^{28,40-42}$ and trialkylamine-based monomers, such as DMAEMA, ${ }^{23,28,31,35,36,40,42-56}$ have been previously used in the synthesis of star polymers for nucleic acid delivery. However, most synthetic procedures for both the star polymers and their linear precursors use organic solvents, such as tetrahydrofuran (THF), 23,36,45,47,49-51,55,56 N,N-dimethylformamide (DMF), ${ }^{31,35,51}$ toluene, ${ }^{43,54} \mathrm{~N}, N$-dimethylacetamide ${ }^{40,44,53}$ pyridine, $^{45}$ anisole $^{42}$ acetone $^{28}$ and 1,2dichlorobenzene. ${ }^{52}$ As recently purported by Prat et al., ${ }^{57}$ all of these solvents were ranked either as 'hazardous' that should be avoided, or as 'problematic', which can affect the toxicity of the resulting star polymer. On the other hand, alcohols, such as ethanol and methanol, were reported as 'recommended', suggesting that these solvents are good alternatives that can potentially improve the star polymer biocompatibility.
A few studies in the literature indicated that the use of emulsions or dispersions, or poorly soluble cross-linkers can improve the "arm-first" star polymer $\oslash$ values. ${ }^{58,59}$ However, these studies were performed either in organic solvents (acetonitrile), ${ }^{58}$ and/or high polymerization temperatures $\left(70{ }^{\circ} \mathrm{C}\right)^{58,59}$ and/or long reaction times $(24 \mathrm{~h})$. An and coworkers, ${ }^{59-63}$ Wang et al., ${ }^{64}$ Tucker et al. ${ }^{65}$ and more recently Chen et al. ${ }^{66}$ used a more biologically-friendly methodology, RAFT heterogeneous emulsion and dispersion polymerization in water or water/alcohol mixtures, to prepare star polymers with low $D$ values in high yields and high solids content. This synthetic methodology appears to be promising for the development of highly biocompatible star polymer vehicles for nucleic acid delivery.

Herein, the preparation of novel star polymers with diacetal bis[(2-methacryloyloxy)ethoxymethyl] ether (MOEME)-based cores by a facile polymerization methodology in water at $37{ }^{\circ} \mathrm{C}$ is presented (Scheme 1). The star polymer arms are prepared by the neutral POEGMA, ${ }^{15,67}$ the positively charged PDMAEMA, ${ }^{8}$ and their mixtures. The star polymer core has the ability to degrade in acidic conditions, such as the low $\mathrm{pH}$ of the cell endosome, resulting in collapse of the star polymer structure. ${ }^{26,34}$ The cytotoxicity, DNA-binding ability and transfection efficiency of the degradable MOEME-based star polymers is presented and compared to non-degradable EGDMAbased star polymers. Based on our knowledge, this is the first report on preparation of star polymers with acid-labile cores in biologically-friendly conditions (ethanol, water, body temperature), which is very significant for the development of these carriers. This is also the first gene delivery study for star polymers prepared by "arm-first" heterogeneous RAFT polymerization.

\section{Experimental}

\section{Materials}

All chemicals were purchased from Sigma-Aldrich and were $>97.0 \%$ purity unless stated otherwise. Paraformaldehyde (95\%) was purchased from Sigma-Aldrich. Methanol (HPLC grade) and ethyl acetate (reagent grade) were purchased from Fisher Scientific. Ethanol (industrial) was purchased from Laboratory Supplies \& Instruments Ltd. Hexane was purchased from T.E Laboratories. 2,2'-Azobis[2-(2-imidazolin-2-yl) propane]dihydrochloride (VA-044) was purchased from Wako Speciality Chemicals. RAW 264.7 cells and 293T cells were obtained from the American Type Culture Collection (ATCC). Phosphate buffer saline tablets (PBS tablets), fetal calf serum (FCS), Dulbecco's Modified Eagle's medium (high-glucose) (DMEM) and penicillin streptomycin were purchased from GIBCO (ThermoFisher Scientific). Cell culture treated consumables including flasks (T175, T80, T25), plates (96, 24, 12 and 6 well), Petri dishes (P90) and cryotubes $(1.8 \mathrm{ml})$ were sourced from Nunc (Life Technologies, Paisley, United Kingdom). CellTitre-Glo (CTG) reagent was obtained from Promega Corporation. Ethylenediaminetetraacetic acid (EDTA) was pur- 


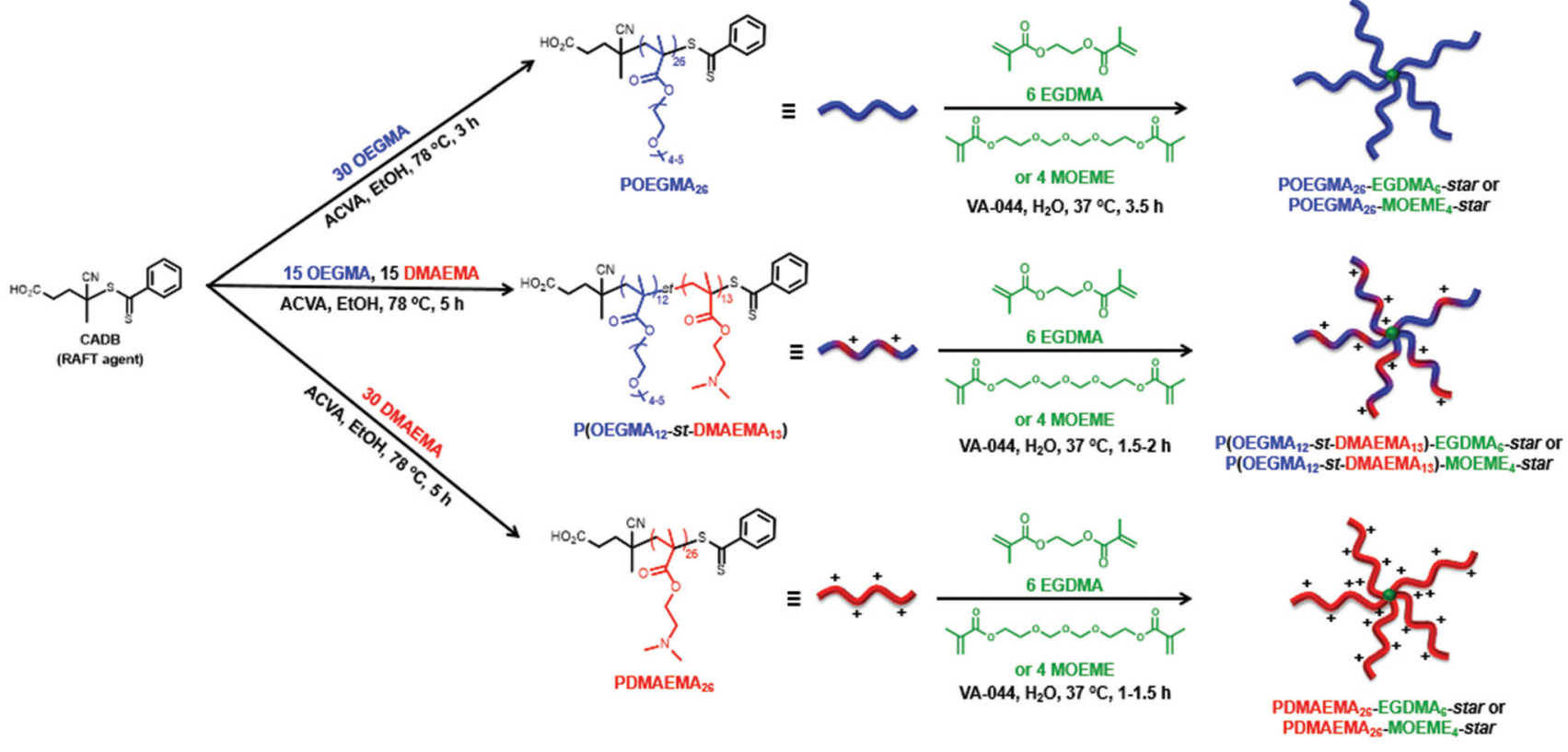

Scheme 1 Synthetic sequences employed for the preparation of the star polymers of this study by RAFT polymerization. CADB = 4-cyano-4-(phenylcarbonothioylthio)pentanoic acid, RAFT agent; OEGMA = oligo(ethylene glycol)methacrylate, neutral monomer; DMAEMA = 2-(dimethylamino) ethyl methacrylate, cationic monomer; $A C V A=4,4$ '-azobis(4-cyanovaleric acid), polymerization initiator; EtOH = ethanol, polymerization solvent; EGDMA = ethylene glycol dimethacrylate; non-degradable cross-linker; MOEME = bis[(2-methacryloyloxy)ethoxymethyl $]$ ether, degradable crosslinker; VA-044 = 2,2'-azobis[2-(2-imidazolin-2-yl)propane]dihydrochloride, polymerization initiator.

chased from Melford Laboratories Ltd. Acetic acid was purchased from VWR International. Bluejuice loading buffer and UltraPure Agarose were purchased from Invitrogen. Calcein and acridine orange were obtained from Life Technologies. Vectashield antifade mounting medium with DAPI was acquired from Vector Laboratories. eGFP and pDQ EV (His) plasmids were kindly provided by Dr James Burrows (Queen's University Belfast).

Both OEGMA and DMAEMA monomers were passed through a basic alumina column before use to remove any radical inhibitors. The diacetal-based MOEME cross-linker was prepared in-house using the experimental procedure described by Themistou et al. ${ }^{32}$

\section{Polymer characterization}

All proton nuclear magnetic $\left({ }^{1} \mathrm{H}\right.$ NMR) spectroscopic analyses were performed using a Bruker Advance $400 \mathrm{MHz}$ spectrometer in deuterated chloroform $\left(\mathrm{CDCl}_{3}\right)$ or $\mathrm{CDCl}_{3} /$ deuterated methanol (MeOD) mixtures. SEC measurements to assess the molecular weight distributions (MWDs) of the star polymers, their linear precursors called macro-chain transfer agents (macro-CTAs) and their degradation products were performed using an Agilent Technologies 1260 Infinity SEC system with a Cirrus software and a refractive index (RI) detector maintained at $30{ }^{\circ} \mathrm{C}$. The instrument setup was comprised of a guard column followed by two Agilent PL gel $5 \mu \mathrm{m}$ MIXED-C columns operating at $25{ }^{\circ} \mathrm{C}$. The eluent used was THF (HPLC grade) containing $2.0 \% \mathrm{v} / \mathrm{v}$ triethylamine and $0.05 \% \mathrm{w} / \mathrm{v}$ butylated hydroxytoluene inhibitor at a flow rate of $1.0 \mathrm{~mL} \mathrm{~min} \mathrm{mi}^{-1}$.
Dimethyl sulfoxide (DMSO) was used as a flow rate marker. A series of ten near-monodisperse Agilent EasiVial poly(methyl methacrylate) standards with MWs of 1010, 1950, 6850, 13900 , 31 110, 68 750, $137800,320000,569000$ and $1048000 \mathrm{~g} \mathrm{~mol}^{-1}$ were used for calibrating the SEC instrument. Dynamic light scattering (DLS) experiments using a detection angle of $173^{\circ}$ (back scattering) (conducted in triplicate, star polymer solution concentrations of $1 \mathrm{mg} \mathrm{mL}^{-1}$ in PBS buffer) and zeta potential measurements were recorded using a Malvern Zetasizer Nano Series ZS instrument operating at $25{ }^{\circ} \mathrm{C}$ with a $633 \mathrm{~nm}$ (red) laser diode. Transmission electron microscopy (TEM) imaging was conducted using a JEOL1200 EXII instrument operating at $120 \mathrm{kV}$ equipped with a numerical camera. $5 \mu \mathrm{L}$ of a $0.2 \mathrm{mg} \mathrm{mL}^{-1}$ star polymer solution was placed onto a carbon-coated copper grid, stained using an aqueous solution of 99.98\% ammonium molybdate, and then dried under ambient conditions.

\section{Synthesis of macro-CTAs}

The same general RAFT polymerization procedure was used for the synthesis of POEGMA ${ }_{26}$, PDMAEMA $_{26}$ and P(OEGMA $12^{-}$ $s t$-DMAEMA $\mathrm{D}_{13}$ ) macro-CTAs. For the latter, a 1:1 molar ratio mixture of the two monomers was used. A typical polymerization yielding the PDMAEMA macro-CTA is detailed next. 4-Cyano-4-(phenylcarbonothioylthio)pentanoic acid (CADB) RAFT agent (11.85 mg, 1.00 equiv., $4.2 \mathrm{mmol}$ ) and DMAEMA monomer (20 g, 30.00 equiv., $127.2 \mathrm{mmol}$ ) were added to a $100 \mathrm{~mL}$ round bottom flask equipped with a magnetic stirring bar and a rubber septum. Ethanol $(27.19 \mathrm{~mL})$ was then added 
to the flask and the resulting solution was purged with nitrogen gas for $20 \mathrm{~min}$. Subsequently, 4,4'-azobis(4-cyanovaleric acid) (ACVA, $297.16 \mathrm{mg}, 0.25$ equiv., $1.06 \mathrm{mmol}$ ) was added to the reaction mixture to give a $50 \% \mathrm{w} / \mathrm{w}$ solids content and the solution was bubbled with nitrogen gas for a further $20 \mathrm{~min}$. The degassed solution was placed in an oil bath at $78^{\circ} \mathrm{C}$ and the reaction was left to proceed for $5 \mathrm{~h}$. The reaction was then quenched by cooling at $0{ }^{\circ} \mathrm{C}$ and exposing the contents to air (final DMAEMA monomer conversion $=87.6 \%$ as judged by ${ }^{1} \mathrm{H}$ NMR spectroscopy, NMR solvent $\mathrm{CDCl}_{3}$ ). The pure macroCTA was obtained by dialysis of the crude product against methanol (10 times, MW cut-off (MWCO) of $1000 \mathrm{~g} \mathrm{~mol}^{-1}$ ) and drying under vacuum. The polymer was characterized by ${ }^{1} \mathrm{H}$ NMR spectroscopy and SEC (THF), giving MW and dispersity $(\boxplus)$ values of $4370 \mathrm{~g} \mathrm{~mol}^{-1}$ and 1.21 , respectively. For the $\mathrm{P}\left(\mathrm{OEGMA}_{12}\right.$-st-DMAEMA $\left.\mathrm{DA}_{13}\right)$ macro-CTA the reaction was also left to proceed for $5 \mathrm{~h}$, whereas only $3 \mathrm{~h}$ were needed for POEGMA $_{26}$ to reach high conversion under the same conditions. The monomer conversions and MW by ${ }^{1} \mathrm{H}$ NMR spectroscopy, and the number-average molecular weight $\left(M_{\mathrm{n}}\right)$ and $Ð$ values by SEC, for all macro-CTAs are presented in Table 1.

\section{Synthesis of acid-labile MOEME-based and non-labile EGDMA- based star polymers in water}

All PDMAEMA ${ }_{26}$, POEGMA $_{26}$ and P(OEGMA 12 -st-DMAEMA 13$)$ based star polymers were prepared by RAFT polymerization in water using similar conditions (Scheme 1). For the acid-labile MOEME-based star polymers, a 4:1 molar ratio of MOEME : macro-CTA was used, whereas for the EGDMA-based star polymers a 6:1 molar ratio of EGDMA: macro-CTA was used. For example, for the synthesis of the acid-labile PDMAEMA $_{26}-\mathrm{MOEME}_{4}$-star at $15 \% \mathrm{w} / \mathrm{w}$ solids content in water, PDMAEMA $_{26}$ macro-CTA (3.00 g, 1.00 equiv., $\left.0.689 \mathrm{mmol}\right)$, MOEME cross-linker ( $844.6 \mathrm{mg}, 4.00$ equiv., $2.748 \mathrm{mmol}$ ) and $22.42 \mathrm{~mL}$ of deionized water were added to a $50 \mathrm{~mL}$ round bottom flask equipped with a magnetic stirring bar and a rubber septum. The contents of the flask were sonicated and vortexed until a homogeneous mixture was obtained. The resulting solution was bubbled with nitrogen gas for $20 \mathrm{~min}$. VA-044 (111.07 mg, 0.50 equiv., $0.344 \mathrm{mmol}$ ) was added to the flask and the solution was degassed further using nitrogen gas for $20 \mathrm{~min}$. The mixture was inserted in an oil bath at $37^{\circ} \mathrm{C}$ and the reaction was quenched after $1.5 \mathrm{~h}$ by cooling at $0{ }^{\circ} \mathrm{C}$ and exposing the contents to air. Different reaction times were used for each reaction (Scheme 1) for star polymer formation due to differences between the reactivities of the macro-CTAs and the cross-linkers. The final star polymer reaction products were characterized by SEC.

\section{Star polymer purification}

After their synthesis, the star polymers were diluted 1:9 with deionized water and subsequently purified from their linear precursors by filter centrifugation using Amicon Ultra-15 filter units (Merck, MWCO $=30000 \mathrm{~g} \mathrm{~mol}^{-1}$ ) and an Eppendorf 5804 centrifuge at $4200 \mathrm{rpm}$ ( 6 washes). After purification the star polymers were freeze dried to give a pink powder and characterized by ${ }^{1} \mathrm{H}$ NMR and SEC.

\section{Star polymer degradation in acidic conditions}

The MOEME-based star polymers were degraded successfully in water in the presence of hydrochloric acid at room temperature. $60.0 \mathrm{mg}$ of each purified and freeze-dried star polymer were dissolved in $2 \mathrm{~mL}$ of $2 \mathrm{M} \mathrm{HCl}$ and stirred at $600 \mathrm{rpm}$ at room temperature for 17 days. The degradation products were analyzed using SEC. For the SEC sample preparation, $1 \mathrm{~mL}$ of each sample was diluted with $9 \mathrm{~mL}$ SEC eluent (THF), resulting in the formation of two distinct layers. The pink/brown color of the bottom aqueous layer indicated the presence of the polymer. The solutions were neutralized by addition of 4 drops of $10 \mathrm{M} \mathrm{NaOH}$ and shaken vigorously, resulting in the transfer of the polymers to the organic (THF) layer, as indicated by the presence of color in the top layer. The samples were left to equilibrate for $3 \mathrm{~h}$ before $2 \mathrm{~mL}$ of the organic layer was extracted using a pipette and filtered through a $0.45 \mu \mathrm{m}$ syringe filter. The filtered solutions were analyzed by SEC. After 17 days, the degradation of the MOEME-based star polymer structures to linear polymers reached almost completion based on the observed SEC MWDs, whereas the non-degradable EGDMA-based star polymers showed no (or minimal) formation of linear polymers.

\section{Star polymer cytotoxicity}

Cytotoxicity of the star polymers was investigated in RAW 264.7 macrophages. This cell line was chosen as it has been previously shown to be capable of achieving high levels of polymer nanoformulation uptake/internalization. As such, it has been used extensively in the literature for evaluation of formulation cytotoxicity. ${ }^{68,69}$ RAW 264.7 cells were acquired from ATCC and cultured in high glucose DMEM supplemented with $10 \%$ EFFCS. Cell viability was assessed via CTG assay

Table 1 Reaction times, monomer conversions, MWs and PDI values for the synthesized macro-CTAs prepared via RAFT solution polymerization in ethanol at $78^{\circ} \mathrm{C}$

\begin{tabular}{llcccrr}
\hline Entry & Macro-CTA targeted structure & $\begin{array}{c}\text { Reaction } \\
\text { time }[\mathrm{h}]\end{array}$ & $\begin{array}{c}\text { OEGMA \% } \\
\text { conversion }\end{array}$ & $\begin{array}{c}\text { DMAEMA \% } \\
\text { conversion }\end{array}$ & $\begin{array}{c}\mathrm{MW}^{a} \\
{[\mathrm{~g} \mathrm{~mol}}\end{array}$ & $\begin{array}{c}M_{\mathrm{n}}{ }^{b} \\
{\left[\mathrm{~g} \mathrm{~mol}^{-1}\right]}\end{array}$ \\
\hline M1 & POEGMA $_{30}$ & 3 & 88.0 & - & 8080 & 8800 \\
M2 & PDMAEMA $_{30}$ & 5 & - & 87.6 & 4370 & 4800 \\
M3 & P(OEGMA $_{15}-$ St-DMAEMA & & 1.23 \\
15 & 5 & 77.9 & 88.0 & 5920 & 7300
\end{tabular}

${ }^{a}$ Data obtained by ${ }^{1} \mathrm{H}$ NMR $\left(400 \mathrm{MHz}\right.$, NMR solvent $\left.=\mathrm{CDCl}_{3}\right) .{ }^{b}$ Data obtained by SEC (THF). 
(Promega). RAW 264.7 cells were seeded in 96-well plates at 2500 cells per well and allowed to adhere overnight. Cells were subsequently treated and incubated at $37^{\circ} \mathrm{C}$ for $48 \mathrm{~h}$. After the treatment period, CTG assay was performed as per manufacturer's instructions.

Luminescence was measured (Biotek Synergy II) and viability of treated cells was expressed relative to that of control cells.

\section{Star polymer-DNA conjugation}

The complexation of pDQ EV (His) plasmid DNA with the star polymers was investigated by electrophoresis on agarose gel. $1.5 \% \mathrm{w} / \mathrm{v}$ agarose gels were prepared in Tris-acetate-EDTA buffer containing $0.01 \% \mathrm{v} / \mathrm{v}$ ethidium bromide. Complexes were prepared at varying polymer: plasmid DNA ratios. These samples were then mixed using a vortex mixer and incubated at room temperature for $30 \mathrm{~min}$. Complexes were mixed with Bluejuice loading buffer (Invitrogen), volumes equilibrated using TE buffer and added to the gel alongside controls for free plasmid and free polymer. Gel electrophoresis was conducted at a constant $100 \mathrm{mV}$ for $1 \mathrm{~h}$, with the gel then imaged on a UV trans-illuminator (MiniBIS Pro, DNR Bio-imaging systems).

\section{Star polymer-DNA transfection}

Transfection was investigated in the 293T cell line, a more biologically relevant model for the investigation of transfection efficiency. HEK293 and 293T cells have a long-standing history of use in the expression of recombinant proteins. The popularity of these cell lines for this purpose is predominantly as a result of their amenability to transfection using a variety of approaches and the subsequently high transfection efficiency that can be obtained. ${ }^{70,71} 293$ T cells were acquired from ATCC and cultured in high glucose DMEM supplemented with $10 \%$ FCS. Cells were seeded in 6-well plates at 70000 cells per well and allowed to adhere overnight. Complexes of star polymers and eGFP plasmid were prepared at varying plasmid DNA : star polymer mass ratios. These samples were then mixed using a vortex mixer and incubated at room temperature for $30 \mathrm{~min}$. Cells were subsequently treated and incubated at $37^{\circ} \mathrm{C}$ for 48 h. After the treatment period, transfection was assessed qualitatively by fluorescence microscopy (EVOS FL Cell Imaging System) and quantitatively by flow cytometry (BD Accuri C6 Plus Flow Cytometer).

\section{Star polymer induced endo/lysosome destabilization}

The ability of the star polymers to escape the endo/lysosomal compartments was assessed by two methods; calcein localization by confocal microscopy and acridine orange staining by flow cytometry.

For calcein localization studies, RAW 264.7 cells (acquired from ATCC and cultured in high glucose DMEM supplemented with $10 \%$ endotoxin free FCS) were seeded in 8-well confocal slides at 20000 cells per well and allowed to adhere overnight. Cells were subsequently treated with calcein $\left(2 \mathrm{mg} \mathrm{mL}^{-1}\right.$ in cell culture media) \pm star polymer $\left(0.25 \mathrm{mg} \mathrm{mL}^{-1}\right.$ in PBS buffer) for $3 \mathrm{~h}$. On the completion of the treatment period, cells were washed with PBS $(\times 3)$ and fixed with $4 \%$ w/v paraformaldehyde in PBS for 20 min. Following further washes in PBS $(\times 3)$, cells were permeabilized with $0.5 \% \mathrm{v} / \mathrm{v}$ Triton $\mathrm{X}-100$ in PBS for $5 \mathrm{~min}$. Cells were then washed with PBS buffer $(\times 3)$ and coverslips were added post application of Vectashield antifade mounting medium with DAPI (Vector Laboratories). Slides were viewed on a SP8 confocal microscope (Leica Microsystems) equipped with LAS AF software. Images were captured with a $\times 40$ lens zoomed $\times 1-4,512 \times 512$ frame and $200 \mathrm{~Hz}$ scanning speed.

For acridine orange endo/lysosomal integrity assays, RAW 264.7 cells were seeded in 6-well tissue culture plates at 70000 cells per well and allowed to adhere overnight. Cells were subsequently treated with star polymer $\left(0.125 \mathrm{mg} \mathrm{mL}^{-1}\right)$ for $24 \mathrm{~h}$. After the treatment period, cells were washed with PBS buffer, trypsinized and pelleted by centrifugation. Cells were then resuspended in PBS buffer containing $1 \mu \mathrm{g} \mathrm{mL} \mathrm{m}^{-1}$ acridine orange and incubated for $15 \mathrm{~min}$ at $37^{\circ} \mathrm{C}$. Sample analysis was then conducted by flow cytometry (BD Accuri C6 Plus Flow Cytometer).

\section{Statistical analyses}

Statistical tests were performed using GraphPad Prism software (version 6.0). Statistical tests were employed as detailed in each figure legend. Where three or more groups were present, one way analysis of variance (ANOVA) was utilized. Statistical significance is highlighted by asterisks on the graphs, which are then defined in the corresponding figure legends.

\section{Results and discussion}

In order to investigate the effect of changing the star polymer arm and core composition on their properties, a series of six star polymers was prepared (Scheme 1). Their synthesis, via 'arm-first' methodology, is based on the ability of RAFT polymerization to produce linear "living" polymers (macroCTAs) upon reaction of a methacrylic monomer (or mixtures of monomers) with a RAFT agent and an initiator, and their subsequent reaction with a dimethacrylate cross-linker. ${ }^{10}$ Here, all linear macro-CTA precursors were prepared in ethanol, while the star polymer synthesis was performed in water. The star polymer arms (macro-CTAs) were designed so that they have distinct charge densities by varying the amount of the neutral OEGMA and the cationic DMAEMA monomers. The PEG repeating units of POEGMA endow the resulting star polymer with 'stealth-like' properties that shield it from protein opsonisation to enhance circulation half-life. ${ }^{72,73}$ The cationic at $\mathrm{pH}$ 7 PDMAEMA is able to form strong electrostatic interactions with the negatively charged DNA at physiological $\mathrm{pH}^{8,74}$ However, polycationic carriers are known to be intrinsically cytotoxic. $^{75,76}$ To combine the desirable properties of these two monomers, i.e. biocompatibility of OEGMA and positive charge of DMAEMA, a $1: 1$ statistical copolymer $\mathrm{P}\left(\mathrm{OEGMA}_{12}\right.$-stDMAEMA $_{13}$ ) (Scheme 1) was also prepared. Both acid-labile MOEME-based and non-labile EGDMA-based star polymers 
were prepared. Their toxicity, DNA complexation, transfection ability and escape from endosomal compartments were evaluated.

\section{Preparation of macro-CTAs}

Three hydrophilic macro-CTAs, POEGMA, PDMAEMA and $\mathrm{P}$ (OEGMA-st-DMAEMA) were prepared in ethanol using similar conditions (Scheme 1). Their successful preparation was confirmed by ${ }^{1} \mathrm{H}$ NMR spectroscopy in $\mathrm{CDCl}_{3}$ and SEC in THF. As shown in Table 1, high monomer conversions (78\%-88\%) in ethanol at $78{ }^{\circ} \mathrm{C}$ within $3-5 \mathrm{~h}$ were achieved as judged by ${ }^{1} \mathrm{H}$ NMR spectroscopy. These values were obtained by comparing the area under the monomer methacrylic peaks at 5.58 and $6.14 \mathrm{ppm}$ to the area of the combined broad polymer/ monomer signals at $4.09 \mathrm{ppm}$ (for POEGMA) and $2.57 \mathrm{ppm}$ (for PDMAEMA). The obtained monomer conversions correspond to POEGMA, PDMAEMA and P(OEGMA-st-DMAEMA) macro-CTAs with mean degree of polymerization (DP) of 26, 26 and 12/13, giving MWs of $8080 \mathrm{~g} \mathrm{~mol}^{-1}, 4370 \mathrm{~g} \mathrm{~mol}^{-1}$, and $5920 \mathrm{~g} \mathrm{~mol}^{-1}$, respectively (Table 1). The ${ }^{1} \mathrm{H}$ NMR polymer characteristic peaks of the purified (by dialysis in methanol) dried macro-CTAs are presented in Fig. S1. $\dagger$ The SEC (THF) data (Fig. S2 $\uparrow$ and Table 1) showed narrow MWDs with low $D$ values (1.21-1.23) for all macro-CTAs. Their $M_{\mathrm{n}}$ values were $8800 \mathrm{~g} \mathrm{~mol}^{-1}(D=1.23), 4800 \mathrm{~g} \mathrm{~mol}^{-1}(D=1.21)$ and $7300 \mathrm{~g}$ $\mathrm{mol}^{-1}(D=1.22)$ for POEGMA, PDMAEMA and P(OEGMA-stDMAEMA), respectively. These values were in good agreement with the MW values obtained by ${ }^{1} \mathrm{H}$ NMR spectroscopy (Table 1). As expected, the SEC chromatograms (Fig. S2 $\dagger$ ) show a shift to lower retention times as the MW of the macro-CTA is increased (from PDMAEMA to P(OEGMA-st-DMAEMA) to POEGMA). The slight shoulder at lower retention time (higher MWs) observed in the SEC chromatograms of the OEGMA-containing macro-CTAs was attributed to chain-chain coupling reactions due to traces of EGDMA cross-linker present in the commercially available OEGMA monomer. Since the polymerization reactions were stopped at around 80\% OEGMA monomer conversion, there is a possibility of existence of dangling double bonds from incomplete polymerization of the EGDMA cross-linker, which could react during the formation of the star polymer in the second polymerization step. However, the existence of traces of EGDMA in the OEGMA monomer did not seem to significantly affect the star polymer synthesis.

\section{Preparation of star polymers}

As shown in Scheme 1, the three macro-CTAs were each reacted with either the acid-degradable MOEME or the nondegradable EGDMA cross-linker to generate star polymers via aqueous RAFT polymerization using an 'arm-first' approach. ${ }^{27}$ The MOEME-based star polymers have the ability to break down to linear polymers via a pH-responsive degradation mechanism due to the presence of acid labile (di)acetal groups in the core of their nanostructures, while the EGDMA-based star polymers are relatively stable under these conditions. ${ }^{26,32,34}$

The synthesis of the star polymers was performed in water at $37^{\circ} \mathrm{C}$ in less than 4 hours (Table 2). A cross-linker : macroCTA molar ratio of $4: 1$ was used for the MOEME-based star polymers, while a ratio of $6: 1$ was selected for the EGDMAbased star polymers. These different ratios were used due to the difference in size, solubility and reactivity of the two crosslinkers in aqueous media. When higher than $4: 1$ cross-linker: macro-CTA ratios were used with MOEME cross-linker, it was difficult to monitor the polymerization reaction since star polymer formation occurred in very short reaction times. The PDMAEMA $_{26}$-based star polymers were formed faster than the other star polymers, with formation achieved after $1.5 \mathrm{~h}$ for the PDMAEMA ${ }_{26}$ MOEME $_{4}$-star (Table 2, SP2) and after $1 \mathrm{~h}$ for PDMAEMA $_{26}$-EGDMA $_{6}$-star (Table 2, SP5). This can be attributed to steric factors; the PDMAEMA ${ }_{26}$ macro-CTA had the least bulky side chain, therefore, chain incorporation to the star polymer core was easier. The POEGMA 26 macro-CTA in contrast, had a much bulkier side chain. As such, longer polymerization times of $3.5 \mathrm{~h}$ for the $\mathrm{POEGMA}_{26}-\mathrm{MOEME}_{4}$-star (Table 2, SP1) and POEGMA ${ }_{26}$ EGDMA $_{6}$-star (Table 2, SP4) were needed for star polymer formation. This is in agreement with the findings of An and coworkers, ${ }^{59}$ who also reported easier incorporation of PDMAEMA linear chains in comparison to the bulkier POEGMA chains to the star polymer core during heterogeneous RAFT polymerization. The $\mathrm{P}\left(\mathrm{OEGMA}_{12}\right.$-stDMAEMA $\left._{13}\right)-\mathrm{MOEME}_{4}$-star (Table 2, SP3) and P(OEGMA 12 -stDMAEMA $_{13}$ )-EGDMA ${ }_{6}$-star (Table 2, SP6) were formed at intermediate rates, $2 \mathrm{~h}$ and $1.5 \mathrm{~h}$, respectively. These reaction times were chosen for star polymer formation since longer reaction

Table 2 Solids content, reaction times, MWs, PDI values, fraction of unattached arms, hydrodynamic diameters and zeta potential values for the synthesized star polymers prepared via aqueous RAFT polymerization at $37^{\circ} \mathrm{C}$

\begin{tabular}{|c|c|c|c|c|c|c|c|c|}
\hline Entry & Star polymer structure & $\begin{array}{c}\% \text { solids } \\
\text { content }[\mathrm{w} / \mathrm{w}]\end{array}$ & $\begin{array}{l}\text { Reaction } \\
\text { time }[\mathrm{h}]\end{array}$ & $\begin{array}{l}\text { \% linear } \\
\text { polymer }^{b}\end{array}$ & $\begin{array}{c}M_{\mathrm{n}}{ }^{a} \\
{\left[\mathrm{~g} \mathrm{~mol}^{-1}\right]}\end{array}$ & $Ð$ value $^{a}$ & $\begin{array}{l}\text { Hydrodynamic } \\
\text { diameter }^{c}[\mathrm{~nm}]\end{array}$ & $\begin{array}{c}\text { Zeta potential } \\
{[\mathrm{mV}]}\end{array}$ \\
\hline SP1 & POEGMA $_{26}-\mathrm{MOEME}_{4}$-star & 20.0 & 3.5 & 27.4 & 59200 & 1.24 & 19.1 & $-10 \pm 5.3$ \\
\hline SP3 & $\mathrm{P}\left(\mathrm{OEGMA}_{12}\right.$-st-DMAEMA 13$)-\mathrm{MOEME}_{4}$-star & 20.0 & 2.0 & 34.9 & 75000 & 1.14 & 19.1 & $+10 \pm 6.0$ \\
\hline SP4 & POEGMA $_{26}$-EGDMA 6 -star & 20.0 & 3.5 & 8.0 & 65700 & 1.17 & 17.9 & $-15 \pm 4.7$ \\
\hline SP5 & PDMAEMA $_{26}$-EGDMA 6 -star & 20.0 & 1.0 & 21.7 & 108000 & 1.20 & 22.0 & $+23 \pm 4.6$ \\
\hline SP6 & $\mathrm{P}\left(\mathrm{OEGMA}_{12}\right.$-st-DMAEMA $\left.{ }_{13}\right)-\mathrm{EGDMA}_{6}$-star & 20.0 & 1.5 & 17.0 & 78900 & 1.12 & 19.0 & $+11 \pm 4.2$ \\
\hline
\end{tabular}

${ }^{a}$ Data obtained by SEC (THF) at the end of the polymerization reaction. ${ }^{b}$ Data obtained by SEC (THF) after removal of linear precursor by centrifugation. ${ }^{c}$ Data obtained by DLS intensity-average diameter distribution. 


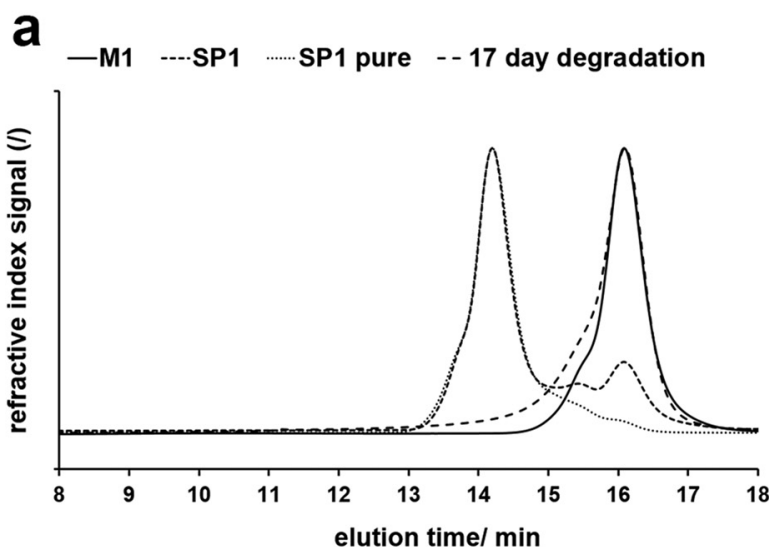

C

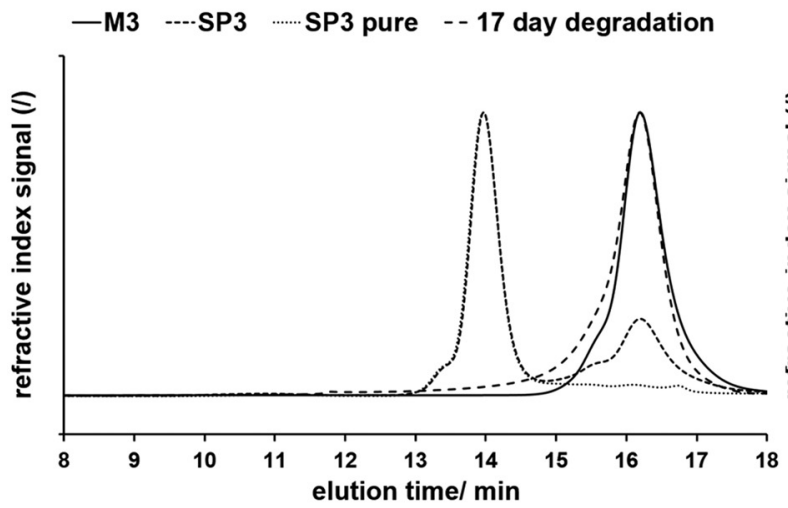

b

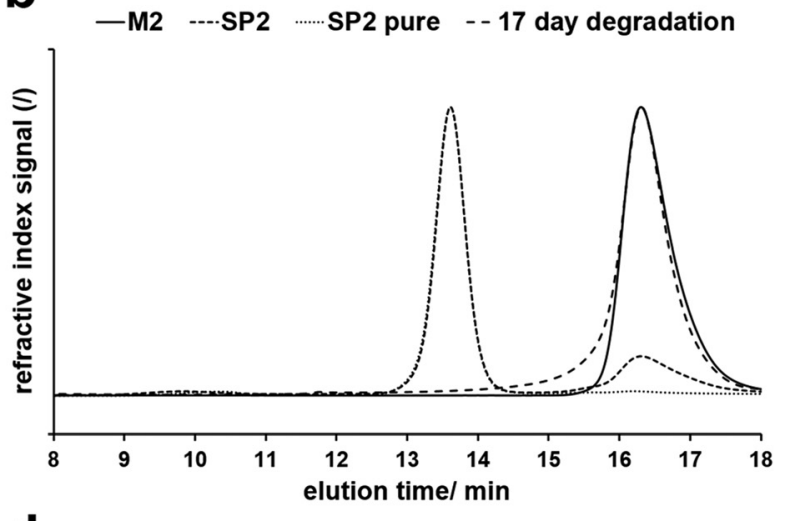

d

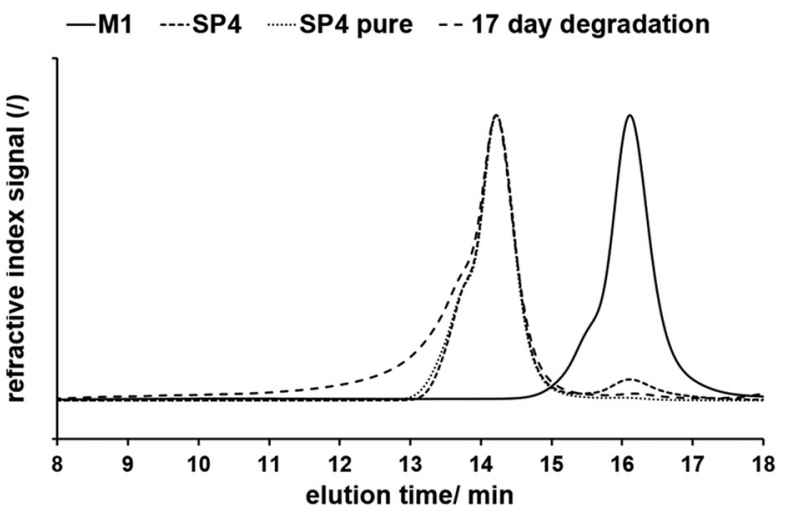

Fig. 1 SEC (THF) chromatograms showing the synthesis (macro-CTA, MX; star polymer, SPX), purification (SPX pure) and acidic degradation (17 day degradation) of (a) POEGMA $26-\mathrm{MOEME}_{4}$-star (SP1); (b) PDMAEMA $26-\mathrm{MOEME}_{4}$-star (SP2); (c) P(OEGMA 12 -st-DMAEMA 13 )-MOEME 4 -star (SP3); and (d) $\mathrm{POEGMA}_{26}-\mathrm{EGDMA}_{6}$-star (SP4) star polymers. POEGMA 26 (M1), PDMAEMA 26 (M2) and P(OEGMA - $_{12}$-st-DMAEMA 13 ) (M3) are the linear macro-CTA precursors.

times tend to give star-star coupling, while shorter reaction times result in a high amount of unattached arms.

The SEC (THF) chromatograms for the MOEME-based star polymers (Fig. 1) showed a clear shift to lower elution times compared to their linear polymer precursors (macro-CTAs), which was indicative of MW increase as a result of the formation of the unique star-shaped architecture. These results confirm the successful interconnection of the arms of the star polymer structures and the adequacy of the cross-linker: macro-CTA molar ratio used (4/1 for MOEME and 6/1 for EGDMA cross linkers). "Arm-first" RAFT polymerization methods for preparing star polymers are known to give incomplete star formation, resulting in the presence of some unreacted linear polymer precursors (i.e. macro-CTAs) that need to be removed after preparation. ${ }^{35,64}$ This was also the case here, where in Fig. 1 the MWDs of all the star polymers appeared to be bimodal. The higher MW peak (lower elution time) belongs to the star polymer, while the lower MW peak (higher elution time) corresponds to the unattached linear polymer. The amount of the linear polymer was calculated by comparing the areas under the two peaks of the chromatogram. The results are shown in Table 2, where the fraction of unreacted linear polymer was higher (between 24\% and 35\%) for the degradable MOEME-based star polymers (Table 2, SP1SP3) compared to the $8 \%$ to $22 \%$ observed for the EGDMAbased star polymers (Table 2, SP4-SP6). These results are in agreement with reports in the literature for polymerizations in organic solvents, where the non-degradable EGDMA crosslinker appears to be more efficient in incorporating linear polymers to the star polymer cores than $\mathrm{MOEME}^{34}$ or other degradable cross-linkers with bulky structures. ${ }^{28,32-34,43,77,78}$

Filter centrifugation was used to purify the star polymers from their linear macro-CTAs. The $M_{\mathrm{n}}$ and $\emptyset$ values obtained by SEC of all the purified star polymers are presented in Table 2 and the SEC chromatograms of the degradable MOEME-based star polymers are presented in Fig. 1 together with one EGDMA-based star polymer, for comparison. After purification (by dialysis), the SEC chromatograms appear to have only one peak that belongs to the star polymer, indicating the successful purification from its linear precursor. The purified star polymer SEC $M_{\mathrm{n}}$ values presented in Table 2, appear to be much higher (7-23 times) than the corresponding values of their linear precursors presented in Table 1 . These $M_{\mathrm{n}}$ results combined with the obtained relatively low $D$ values 
(1.07-1.24), indicate successful preparation and purification of the star polymers.

${ }^{1} \mathrm{H}$ NMR in $\mathrm{CDCl}_{3} / \mathrm{MeOD}$ mixture $(3 / 1 \mathrm{v} / \mathrm{v})$ of the purified star polymers (Fig. S3†) confirmed the presence of the expected DMAEMA and OEGMA peaks for all the star polymers.

The purified star polymers were also characterized by DLS, which gave hydrodynamic diameters in the range of 17-23 nm (Table 2, Fig. 2). TEM imaging for PDMAEMA 26 -MOEME 4 -star was consistent with its DLS data, confirming the size and morphology of the star polymer (Fig. S4†).

As shown in Table 2, zeta potential measurements of all the star polymers gave values ranging from $-15 \mathrm{mV}$ (for POEGMAbased star polymers) to $+23 \mathrm{mV}$ (for PDMAEMA-based star polymers). The observed data showed a clear trend; as the PDMAEMA content increased, and therefore the positive charges on the acid-labile star polymer side chains increased in the order POEGMA $_{26}-\mathrm{MOEME}_{4}$-star $<\mathrm{P}\left(\mathrm{OEGMA}_{12}\right.$-stDMAEMA $_{13}$ )-MOEME - $_{4}$-star < PDMAEMA $_{26}-$ MOEME $_{4}$-star, zeta potential values increased (became more positive). The same trend was also observed with the non-labile EGDMA-based star polymers. The negative values obtained for the POEGMA-based star polymers, POEGMA $26^{-} \mathrm{MOEME}_{4}$-star and POEGMA $_{26}{ }^{-}$ EGDMA $_{6}$-star, can be attributed to the carboxylic acid group of the RAFT agent, which is incorporated at the end of each arm (linear macro-CTA chain) of the star polymers during polymerization.

\section{Degradation of MOEME-based star polymers in acidic conditions}

The incorporation of acid-labile acetal groups in the core of the star polymers endows them with a pH-responsive degradation mechanism that results in low MW linear polymers. $^{26,29,32,34,41,79-82}$ The MOEME cross-linker used here has the ability to degrade to two 2-hydroxylethyl methacrylate (HEMA) units under acidic conditions similar to the ones

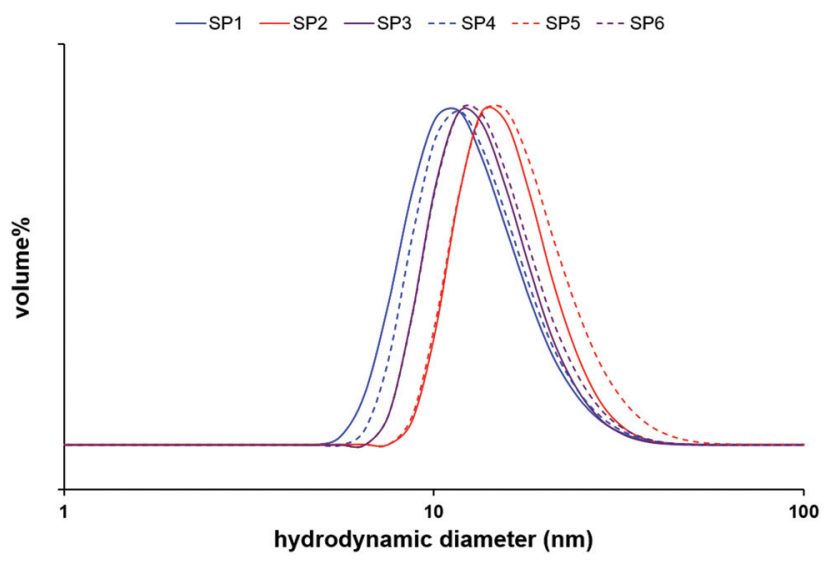

Fig. 2 DLS volume weighted diameter distribution for purified POEGMA $_{26}-\mathrm{MOEME}_{4}$-star (SP1), PDMAEMA $26-\mathrm{MOEME}_{4}$-star (SP2), P(OEGMA 12 -st-DMAEMA 13 )-MOEME 4 -star (SP3), POEGMA 26 -EGDMA - $_{6}$ star (SP4), PDMAEMA $26-$ EGDMA $_{6}$-star (SP5) and P(OEGMA 12 -st$\mathrm{DMAEMA}_{13}$ )-EGDMA $\mathrm{A}_{6}$-star (SP6) star polymers (1 $\mathrm{mg} \mathrm{mL}^{-1}$ in PBS buffer). found in cell endosomal compartments. ${ }^{26,34}$ The complete breakdown of the degradable MOEME-based star polymers to linear polymers in a $2 \mathrm{M}$ hydrochloric acid $(\mathrm{HCl})$ aqueous solution was accomplished in 17 days. The degradation products were analysed by SEC and the results are presented in Fig. 1a-c (17 day degradation). The figures show that all three MOEME-based star polymers were degraded to much lower MW products than the initial star polymers, approaching the MW of their macro-CTA precursors. More specifically, the $M_{\mathrm{n}}$ values of the degradation products POEGMA $_{26}-\mathrm{HEMA}_{8}$, PDMAEMA $_{26}-\mathrm{HEMA}_{8}$ and P(OEGMA 12 -st-DMAEMA $\left.{ }_{13}\right)-\mathrm{HEMA}_{8}$ of POEGMA $_{26}-\mathrm{MOEME}_{4}$-star, PDMAEMA ${ }_{26}-\mathrm{MOEME}_{4}$-star and $\mathrm{P}\left(\mathrm{OEGMA}_{12}\right.$-st-DMAEMA 13 )-MOEME ${ }_{4}$-star were $10700 \mathrm{~g} \mathrm{~mol}^{-1}$ $(Ð=1.51), 10700 \mathrm{~g} \mathrm{~mol}^{-1}(\nexists=1.73)$ and $11800 \mathrm{~g} \mathrm{~mol}^{-1}(\nexists=$ 1.73), respectively. As expected, the $M_{\mathrm{n}}$ (and $\oslash$ ) values of the degradation products are higher that the values of the corresponding macro-CTA linear precursors of these star polymers shown in Table 1, POEGMA $_{26}\left(\mathrm{M} 1, M_{\mathrm{n}}=8800 \mathrm{~g} \mathrm{~mol}^{-1}, \emptyset=\right.$ 1.23), PDMAEMA $_{26}\left(\mathrm{M} 2, M_{\mathrm{n}}=4800 \mathrm{~g} \mathrm{~mol}^{-1}, D=1.21\right)$ and $\mathrm{P}\left(\mathrm{OEGMA}_{12}\right.$-st-DMAEMA $\left.{ }_{13}\right)\left(\mathrm{M} 3, M_{\mathrm{n}}=7300 \mathrm{~g} \mathrm{~mol}^{-1}, \emptyset=1.22\right)$, respectively. This is the case since after the star polymer core degradation, the cross-linker degradation products (PHEMA) will remain attached to the linear polymer chain. Since a $4: 1$ ratio of cross-linker : macro-CTA was used in the star polymer synthesis, and therefore, 4 units of MOEME per chain, with MOEME degradation 8 units of HEMA (MW of $130.14 \mathrm{~g} \mathrm{~mol}^{-1}$ ) would be incorporated to each linear chain. Therefore, the degradation product is expected to have a MW of $1040 \mathrm{~g} \mathrm{~mol}^{-1}$ ( 8 units of HEMA) higher that the macro-CTA. In contrast, as shown in Fig. 1d (17 day degradation), the GPC chromatogram of the degradation product of the POEGMA 26 -EGDMA - -star, is similar to that obtained for the star polymer. Only a very small peak at higher retention time is observed in the degradation product chromatogram, indicating minimal degradation of the star polymer core under the same conditions. This might be due to partial ester bond hydrolysis of EGDMA cross-linker resulting in detachment of a small number of linear chains from the star polymer core, giving the small peak at lower retention times in the chromatogram (indicative of linear polymer formation).

\section{In vitro cytotoxicity of star polymers}

In order to achieve effective expression of transfected DNA in host cells, the toxicity of the DNA carrier to the cells must be minimal. Therefore, the star polymers prepared in this work were assessed for cytotoxicity at concentrations ranging from $0-500 \mu \mathrm{g} \mathrm{mL}{ }^{-1}$. The results from the CTG assay $48 \mathrm{~h}$ post treatment of RAW 264.7 cells with star polymer solutions (Fig. 3) show a clear trend; increasing the amount of PEG in the arms of the star polymer resulted in less reduction in cell viability. More specifically, the star polymers that contain only OEGMA monomer units, POEGMA $26-\mathrm{MOEME}_{4}$-star (Fig. 3c) and POEGMA $_{26}$-EGDMA ${ }_{6}$-star (Fig. 3d), showed minimal reduction in cell viability. Similarly, the $\mathrm{P}\left(\mathrm{OEGMA}_{12}\right.$-st-DMAEMA $\left.\mathrm{DM}_{13}\right)$ MOEME $_{4}$-star (Fig. 3e) and $\mathrm{P}\left(\mathrm{OEGMA}_{12}\right.$-st-DMAEMA 13 EGDMA $_{6}$-star (Fig. 3f) star polymers showed viabilities of 
a

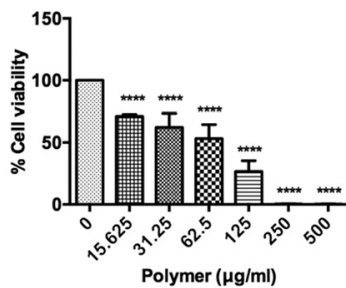

c

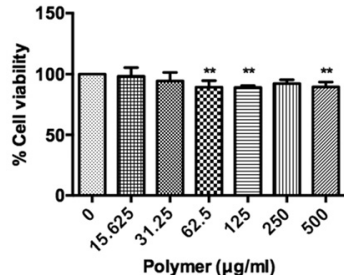

e

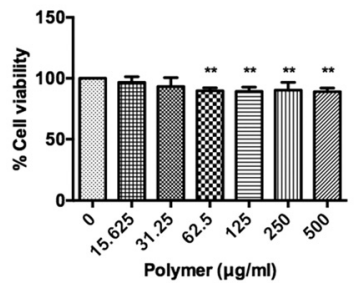

b
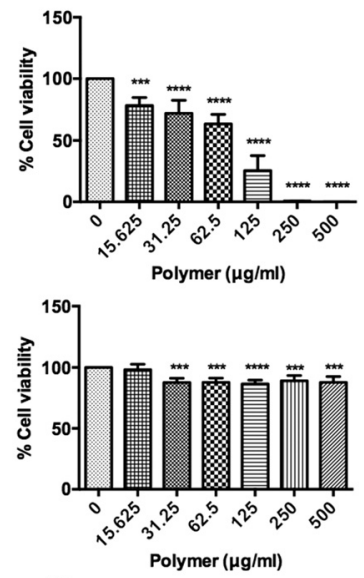

$\mathbf{f}$

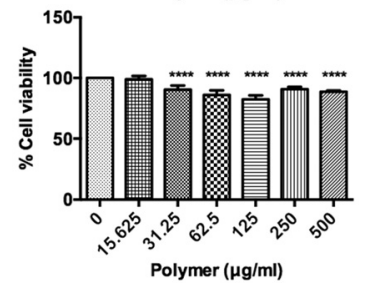

Fig. 3 Cell viability data for (a) purely cationic acid-labile PDMAEMA $26^{-}$ $\mathrm{MOEME}_{4}$-star, (b) purely cationic non-labile PDMAEMA $26-\mathrm{EGDMA}_{6}$-star, (c) neutral acid-labile POEGMA $26-\mathrm{MOEME}_{4}$-star (d) neutral non-labile POEGMA $_{26}-$ EGDMA $_{6}$-star, (e) partially cationic acid-labile P(OEGMA $12^{-}$ st-DMAEMA ${ }_{13}$ )-MOEME - $_{4}$-star and (f) partially cationic non-labile

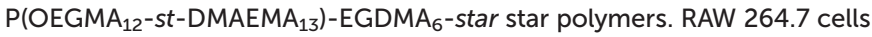
were treated with varying concentrations of star polymer $(0-500 \mu \mathrm{g}$ $\mathrm{mL}^{-1}$ ) and cell viability was assessed via CTG assay $48 \mathrm{~h}$ post treatment. Assay was performed in quadruplicate. Representative of three independent experiments. Statistical significance was established by one-way ANOVA $\left({ }^{* *} p \leq 0.01 ;{ }^{* * *} p \leq 0.001 ;{ }^{* * * *} p \leq 0.0001\right)$

$>90 \%$ even at the highest polymer concentrations assessed. In contrast, cell treatment with the purely cationic star polymers, PDMAEMA $_{26}$-MOEME $_{4}$-star (Fig. 3a) and PDMAEMA $26^{-}$ EGDMA $_{6}$-star (Fig. 3b), resulted in significant reduction in cell viability. This was attributed to the increased positive charge in the arms of these star polymers, which has been previously reported to cause destabilization of the cell membrane, resulting in cell death. ${ }^{83}$ It is important to mention here that the acid-labile MOEME-based and the non-labile EGDMA-based star polymers showed similar cell viabilities. This was expected since, as shown by the SEC data obtained during the degradation study (Fig. 1a-c), the relatively short (48 h) incubation time employed here was not enough to cause complete degradation of the acid-labile MOEME-based cores.

\section{DNA conjugation ability of star polymers}

All the star polymers were examined for their ability to form star polymer-DNA complexes via gel electrophoresis (Fig. 4). Varying amounts of each star polymer $\left(0-500 \mu \mathrm{g} \mathrm{mL}^{-1}\right)$ were mixed with a fixed amount of plasmid DNA $(1 \mu \mathrm{g})$. Full DNA binding was obtained when no DNA was shown to migrate through the electrophoresis gel, instead remaining in the well.
As expected, the fully cationic star polymers, PDMAEMA ${ }_{26}{ }^{-}$ MOEME $_{4}$-star (Fig. 4a) and PDMAEMA 26 -EGDMA 6 -star (Fig. 4b), showed the highest DNA binding, with DNA: polymer mass ratios of 1:5 required for full DNA binding. The neutral POEGMA 26 -MOEME ${ }_{4}$-star (Fig. 4c) and POEGMA $_{26}$-EGDMA 6 -star (Fig. 4d) star polymers showed no DNA binding even at the maximum DNA: polymer mass ratio assessed $(1: 20)$. The trend observed for star polymer-DNA binding can be also attributed to the positive charges present on the star polymer arms at $\mathrm{pH} 7$, which can form electrostatic interactions with the negatively charged DNA. The star polymers with more positive charges (more PDMAEMA units) in their arms appear to yield higher DNA binding.

\section{DNA transfection ability of star polymers}

The ability of each star polymer to successfully complex plasmid DNA and transfect cells was assessed in vitro. For this, $293 \mathrm{~T}$ cells were incubated with star polymer-eGFP plasmid DNA complexes for $48 \mathrm{~h}$, at which point successful transfection was assessed by fluorescent microscopy (Fig. 5). Cells were treated with DNA: star polymer mass ratios of $1: 30$ and $1: 40$. Under these treatment conditions both DNA complexes with the purely cationic PDMAEMA $_{26}-\mathrm{MOEME}_{4}$-star and PDMAEMA $_{26}$-EGDMA ${ }_{6}$-star star polymers were capable of successful DNA delivery (Fig. 5a and b). The level of transfection achieved was assessed quantitatively by flow cytometry (Fig. 6). At both ratios examined $(1: 30$ and $1: 40)$, transfection was superior with the purely cationic acid-labile PDMAEMA ${ }_{26}$ MOEME $_{4}$-star complexes compared to the non-labile PDMAEMA $_{26}$-EGDMA ${ }_{6}$-star complexes. Acid-labile PDMAEMA $_{26}$-MOEME ${ }_{4}$-star complexes were capable of transfecting $33.4 \%$ and $65.5 \%$ of cells at DNA : star polymer ratios of $1: 30$ and $1: 40$, respectively, compared to $12.7 \%$ and $44.2 \%$ for the non-labile PDMAEMA ${ }_{26}$ EGDMA $_{6}$-star complexes. The higher transfection efficiency of the acid-labile PDMAEMA ${ }_{26}$ $\mathrm{MOEME}_{4}$-star complexes could be due to increased endosomal escape of the plasmid DNA upon degradation of the PDMAEMA $_{26}$-MOEME 4 -star star polymer within the acidic endosomal environment. To ascertain whether binding with DNA altered the cytotoxicity of the star polymers, cytotoxicities of complexed (DNA:star polymer ratio 1:40) and free PDMAEMA $_{26}-\mathrm{MOEME}_{4}$-star and PDMAEMA 26 -EGDMA ${ }_{6}$-star star polymers were assessed and compared. For all concentrations investigated $\left(0-500 \mu \mathrm{g} \mathrm{mL} \mathrm{m}^{-1}\right)$, the cytotoxicities of the complexed and free star polymers were found to be comparable (Fig. S5†).

At the assessed DNA : star polymer mass ratios, no transfection was apparent for any of the other DNA-star polymer complexes (Fig. 5c-f). This inability to transfect 293T cells was expected for the neutral POEGMA ${ }_{26}-\mathrm{MOEME}_{4}$-star and POEGMA $_{26}$-EGDMA ${ }_{6}$-star complexes (Fig. 5c and d) since their lack of cationic charges does not allow complexation with the plasmid DNA (Fig. 4c and d). On the other hand, while both the partially cationic $\mathrm{P}\left(\mathrm{OEGMA}_{12}\right.$-st-DMAEMA $\mathrm{DMOEME}_{4}$-star and $\mathrm{P}\left(\mathrm{OEGMA}_{12}\right.$-st-DMAEMA $\left.{ }_{13}\right)$-EGDMA $\mathrm{E}_{6}$-star polymers were capable of complexing plasmid DNA (Fig. 4e and f), their 

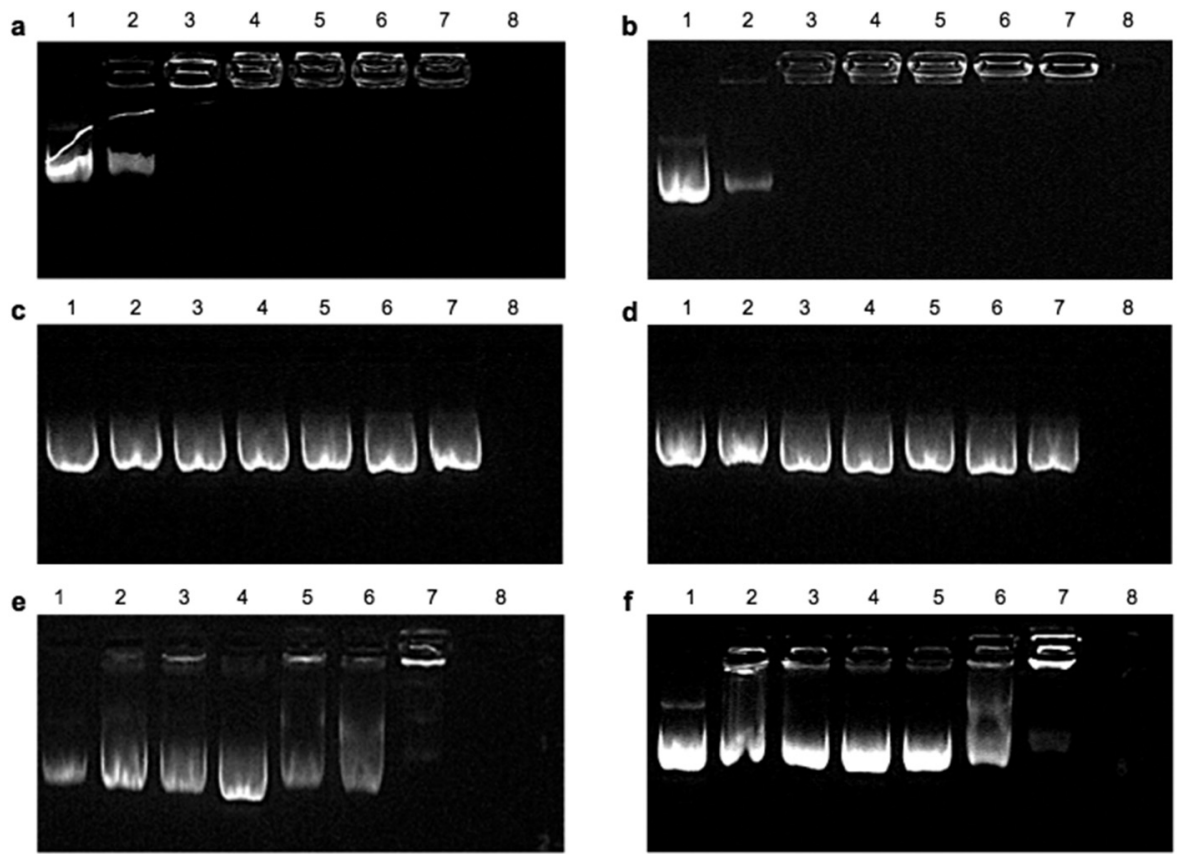

Fig. 4 Gel electrophoresis images for plasmid DNA-star polymer complexes of (a) purely cationic acid-labile PDMAEMA $26-M O E M E_{4}-$ star; $_{\text {; }}(\mathrm{b})$ purely

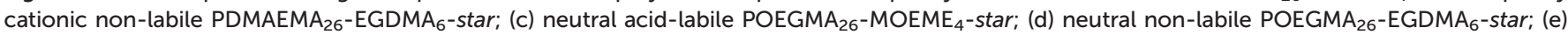
partially cationic acid-labile P(OEGMA 12 -st-DMAEMA $\left.{ }_{13}\right)-\mathrm{MOEME}_{4}$-star; and (f) partially cationic non-labile P(OEGMA ${ }_{12}$-st-DMAEMA 13 )-EGDMA - $_{6}$-star star polymers. In each case the gels present free plasmid (lane 1); DNA : polymer mass ratio 1:2.5 (lane 2), 1:5 (lane 3), 1:7.5 (lane 4), 1:10 (lane 5), $1: 15$ (lane 6), 1:20 (lane 7); and free star polymer (lane 8).

inability to successfully transfect in vitro (Fig. 5e and f) might be the result of reduced cellular internalization and/or reduced endosomal escape compared to the PDMAEMA $_{26}$ MOEME $_{4}$-star and PDMAEMA ${ }_{26}$ EGDMA $_{6}$-star complexes. This inability to successfully deliver plasmid DNA holds true even at higher DNA:star polymer ratios of $1: 80$ and $1: 120$ (Fig. S6†).

\section{Star polymer induces endo/lysosome destabilization}

In order to determine if levels of escape from endosomal compartments was a contributing factor in the differing transfection abilities of the cationic acid-labile star polymers, internalization and endo/lysosomal destabilization were assessed (Fig. 7). RAW 264.7 cells incubated with the cell membrane impermeable fluorescent dye calcein alone exhibited no internalization and subsequent fluorescence (Fig. 7a). Cells that were treated with calcein and the partially cationic acidlabile $\mathrm{P}\left(\mathrm{OEGMA}_{12}\right.$-st-DMAEMA $\left.{ }_{13}\right)$-MOEME $\mathrm{M}_{4}$-star star polymer exhibited minimal levels of calcein internalisation. This, where present, was punctate in nature indicating that the dye is located within the endosomal compartments and in turn, the integrity of these compartments has been maintained (Fig. 7b). Conversely, cells treated with calcein and the purely cationic acid-labile PDMAEMA $_{26}-\mathrm{MOEME}_{4}$-star star polymer (containing much more cationic charge) presented a notably increased calcein signal, indicating increased uptake (of both calcein and star polymer) (Fig. 7c). Furthermore, the calcein appeared diffuse and was distributed broadly throughout the cytosolic space. This implies that the purely cationic degradable PDMAEMA ${ }_{26}-\mathrm{MOEME}_{4}$-star star polymer is capable of destabilizing the endosomal membrane and in turn redistributing the calcein dye into the cytosol.

This ability of the cationic star polymers to escape endosomal compartments was further assessed using acridine orange. ${ }^{84,85}$ Acridine orange accumulates in acidic organelles and exhibits red fluorescence. When the integrity of these compartments is compromised, the fluorescent signal produced dissipates as the dye is released into a more neutral environment. ${ }^{86}$ The majority of cells incubated with acridine orange alone exhibited an intense acridine orange signal (Fig. 7d-f; red histogram). Treatment of cells with the acidlabile purely cationic PDMAEMA $26-\mathrm{MOEME}_{4}$-star star polymer was found to increase the percentage of cells presenting low acridine orange fluorescence (28.7\%) (Fig. 7d). This is indicative of endosomal membrane destabilization and subsequent release of acridine orange into the cytosol. Indeed, this dissipation of acridine orange fluorescence following incubation with PDMAEMA ${ }_{26}-\mathrm{MOEME}_{4}$-star star polymer was shown to be polymer concentration dependent (Fig. S7†). This level of acridine orange release was not evidenced in those cells treated with either the partially cationic acid-labile $\mathrm{P}\left(\mathrm{OEGMA}_{12}\right.$-st-

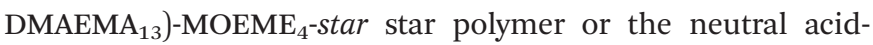
labile POEGMA $_{26}-\mathrm{MOEME}_{4}$-star star polymer (Fig. 7e and f) and as such correlates with the findings from the calcein localization study. It appears therefore that the ability of the most (purely) cationic star polymers (PDMAEMA $26-\mathrm{MOEME}_{4}$-star 
$1: 30$

a

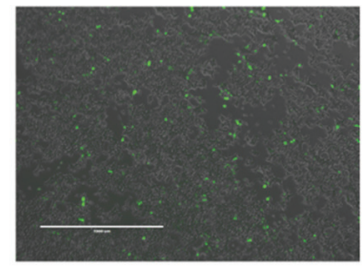

b

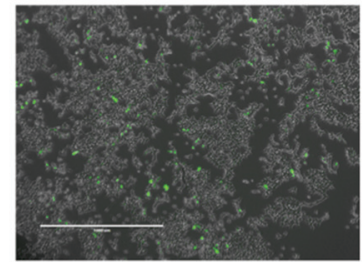

c

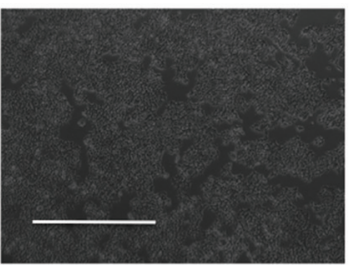

d

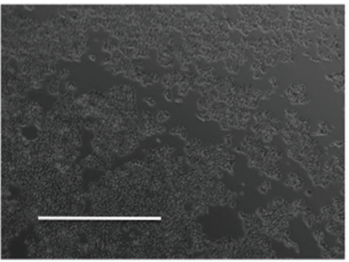

e

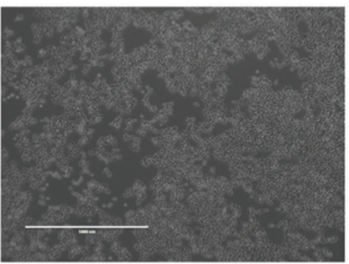

f
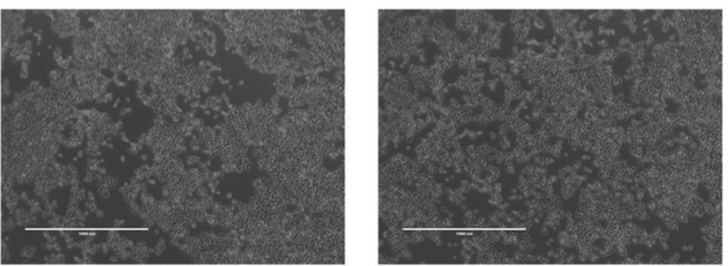

Fig. 5 Purely cationic star polymers are required for efficient transfection. Fluorescent microscopy images of 293T cells transfected for $48 \mathrm{~h}$ with eGFP plasmid DNA-star polymer complexes of (a) purely cationic acid-labile PDMAEMA $26-\mathrm{MOEME}_{4}$-star; (b) purely cationic non-labile PDMAEMA 26 -EGDMA 6 -star; (c) neutral acid-labile POEGMA $26-\mathrm{MOEME}_{4}$ star; (d) neutral non-labile POEGMA ${ }_{26}-\mathrm{EGDMA}_{6}$-star; (e) partially cationic acid-labile $\mathrm{P}\left(\mathrm{OEGMA} \mathrm{A}_{12}\right.$-st-DMAEMA $\left.{ }_{13}\right)-\mathrm{MOEME}_{4}$-star; and (f) partially cationic non-labile P(OEGMA ${ }_{12}$-st-DMAEMA $\left.{ }_{13}\right)$-EGDMA - $_{6}$-star at DNA : star polymer mass ratios of $1: 30$ and $1: 40$. Scale bars $=1000 \mu \mathrm{m}$.

and PDMAEMA ${ }_{26}-$ EGDMA $_{6}$-star) to compromise the integrity of the endosomal compartments is key in allowing the DNA to translocate to the nuclear regions and subsequently transfect the cells. In turn, the inability of the less (partially) cationic star polymers (P(OEGMA-st-DMAEMA)-MOEME-star and P(OEGMA-st-

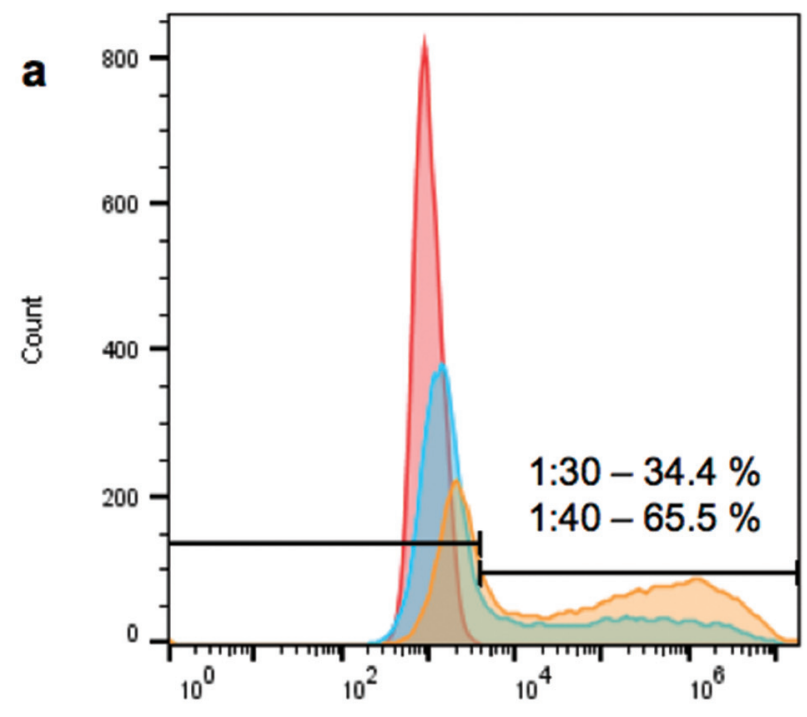

FITC-A

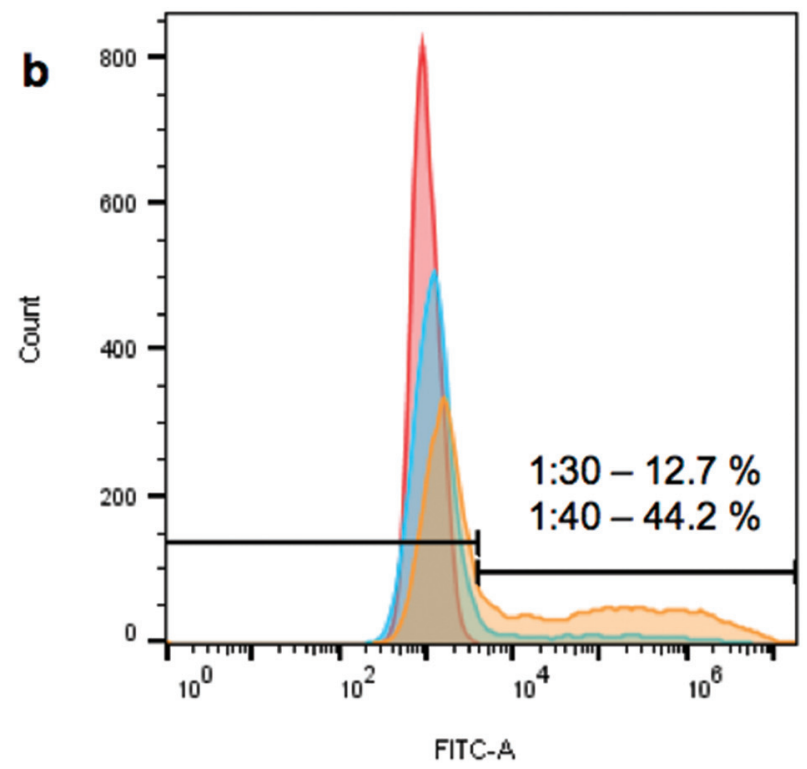

Fig. 6 Acid-labile core enhances purely cationic star polymer transfection efficiency. Assessment of transfection efficiency of 293T cells for (a) purely cationic acid-labile PDMAEMA ${ }_{26}-\mathrm{MOEME}_{4}$-star and (b) purely cationic non-labile PDMAEMA $26-$ EGDMA $_{6}$-star star polymers. Histograms of untreated (red) cell populations and cells treated with DNA:star polymer mass ratios of 1:30 (blue) and 1: 40 (orange) as determined by flow cytometry are presented. Gated regions represent non-GFP positive cells (left) and transfected, GFP positive cells (right). Assay performed in duplicate. Representative of three independent experiments.

DMAEMA)-EGDMA-star) to escape the endosomal pathway appears to be a determining reason for the poor transfection levels observed with these polymers. This endosomal escape has been demonstrated to be facilitated by both increased star polymer arm cationic character and core degradability.

Therefore, further modification is likely to be required to enable optimal DNA delivery. By increasing the proportion of cationic DMAEMA units to neutral OEGMA units on the star 
(a) Calcein
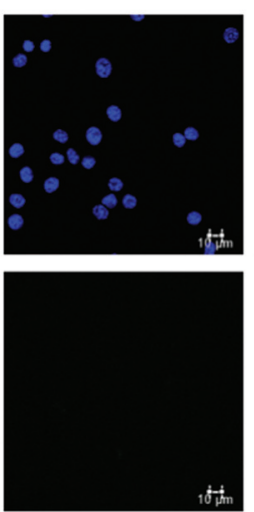

10 itm

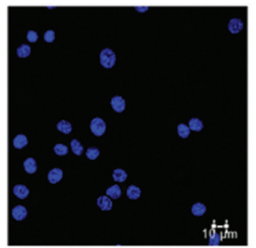

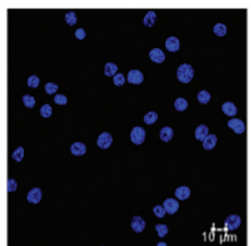

P(OEGMA 1 -st-DMAEMA $\left._{13}\right)-$ MOEME $_{4}$-star
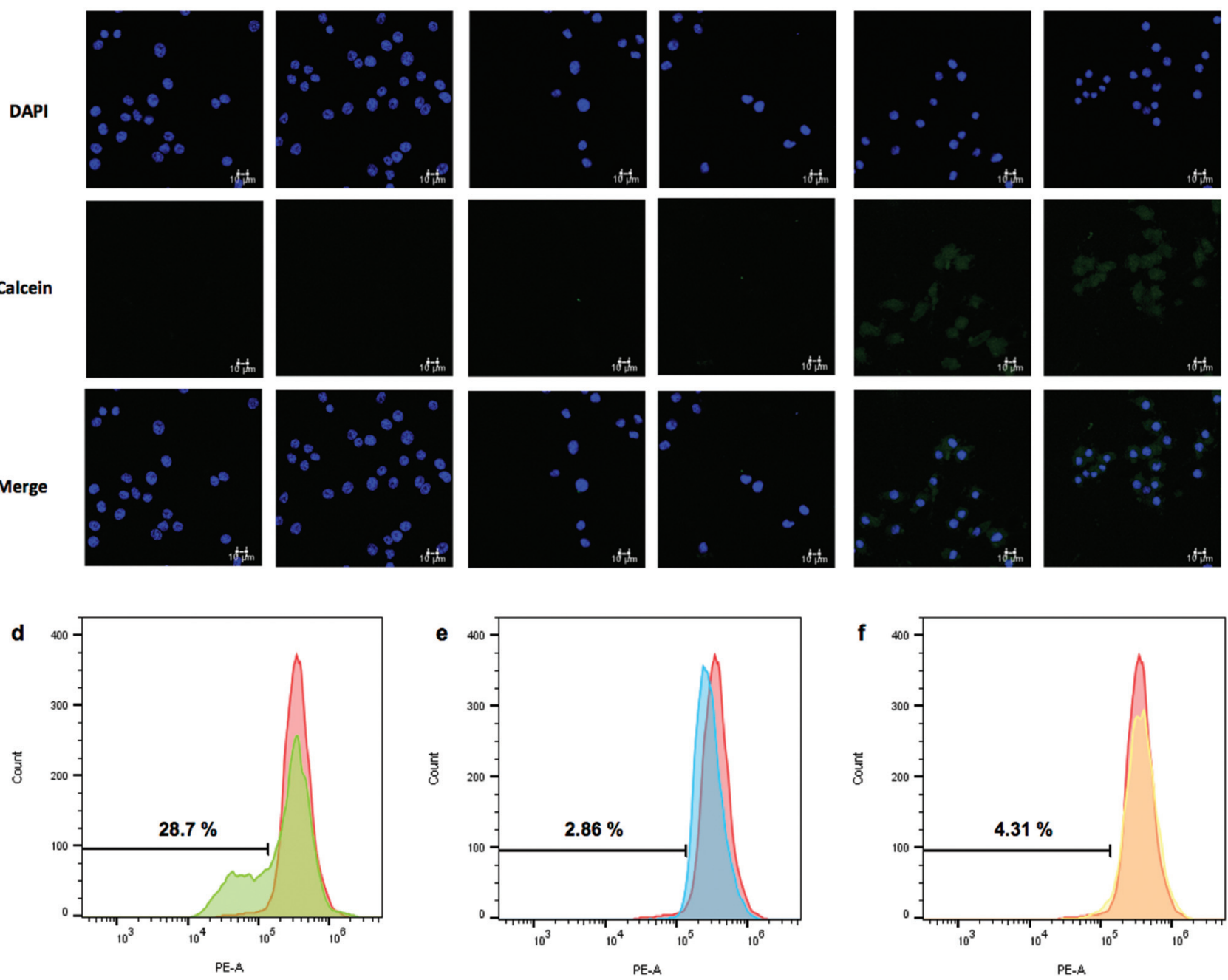

Fig. 7 Star polymers induce varying levels of endo/lysosome destabilization. (a-c) RAW 264.7 cells were incubated in media containing 2 mg $\mathrm{mL}^{-1}$ calcein and $0.25 \mathrm{mg} \mathrm{mL}^{-1}$ star polymer for $3 \mathrm{~h}$. Cells were treated with (a) calcein alone; (b) calcein and partially cationic acid-labile P(OEGMA ${ }_{12}$-st$\mathrm{DMAEMA}_{13}$ )-MOEME $\mathrm{M}_{4}$-star star polymer; and (c) calcein and purely cationic acid-labile PDMAEMA ${ }_{26}-\mathrm{MOEME}_{4}$-star star polymer. Upon completion of treatment, cells were washed, fixed, permeabilized and stained with DAPI prior to assessment by confocal microscopy. Two representative images are presented per treatment group. Scale bars $=10 \mu \mathrm{m}$. (d-f) Endo/lysosome destabilization was also assessed using acridine orange. RAW 264.7 cells were left untreated and then incubated with acridine orange $\left(1 \mu \mathrm{g} \mathrm{mL}^{-1}\right)$ alone (red histogram) or treated with (d) PDMAEMA ${ }_{26}-\mathrm{MOEME}_{4}$-star $\left(0.125 \mathrm{mg} \mathrm{mL}^{-1}\right.$ ) (green histogram); (e) P(OEGMA 12 -st-DMAEMA 13 )-MOEME 4 -star $\left(0.125 \mathrm{mg} \mathrm{mL}^{-1}\right.$ ) (blue histogram); or (f) POEGMA 26 -MOEME - $_{4}$-star $\left(0.125 \mathrm{mg} \mathrm{mL}^{-1}\right.$ ) (orange histogram); for $24 \mathrm{~h}$ and then incubated with acridine orange $\left(1 \mu \mathrm{g} \mathrm{mL}^{-1}\right)$. Histograms of acridine orange fluorescence intensity as determined by flow cytometry are displayed with gated regions indicating percentage of cell population exhibiting low acridine orange signal intensity. Assay performed in duplicate. Representative of three independent experiments.

polymer arms of the P(OEGMA-st-DMAEMA)-MOEME-star and P(OEGMA-st-DMAEMA)-EGDMA-star star polymers, transfection is likely to be attainable, with reduced cytotoxicity compared to the purely cationic PDMAEMA $26-\mathrm{MOEME}_{4}$-star and PDMAEMA $_{26}$-EGDMA ${ }_{6}$-star star polymers.

\section{Conclusions}

The development of nanosized therapeutic systems that enable DNA delivery capabilities has great potential. In this work, the ability of novel acid-labile star polymers to deliver genetic material intracellularly is demonstrated. The star polymers were successfully produced via a highly efficient process; heterogeneous RAFT polymerization in biologically compatible solvents. Their arm cationic charge density was found to be the key determinant of star polymer cytotoxicity and their ability to successfully complex with DNA. Both star polymer cationic charge density and core degradability governed their ability to escape endosomal compartments. This was illustrated to be vital in ensuring successful transfection. Further optimisation of these star polymer formulations should permit 
the production of nanostructures capable of enhanced genetic material binding capabilities with reduced toxicity and in turn, promising vehicles for gene delivery.

\section{Conflicts of interest}

There are no conflicts to declare.

\section{Acknowledgements}

The authors acknowledge the Department for the Economy (DfE), and the Engineering and Physical Sciences Research Council (EPSRC) (S3802ASA) for funding the Ph.D. studentships of T. J. G. and P. S., respectively.

\section{References}

1 H. Yin, R. L. Kanasty, A. A. Eltoukhy, A. J. Vegas, J. R. Dorkin and D. G. Anderson, Nat. Rev. Genet., 2014, 15, 541-555.

2 B. Shi, M. Zheng, W. Tao, R. Chung, D. Jin, D. Ghaffari and O. C. Farokhzad, Biomacromolecules, 2017, 18, 2231-2246.

3 W.-F. Lai and W.-T. Wong, Trends Biotechnol., 2018, 36, 713-728.

4 A. V. Kabanov and V. A. Kabanov, Bioconjugate Chem., 1995, 6, 7-20.

5 D. E. Olins, A. L. Olins and P. H. von Hippel, J. Mol. Biol., 1967, 24, 157-176.

6 J.-P. Behr, Bioconjugate Chem., 1994, 5, 382-389.

7 P. Erbacher, J.-S. Remy and J.-P. Behr, Gene Ther., 1999, 6, 138-145.

8 S. Agarwal, Y. Zhang, S. Maji and A. Greiner, Mater. Today, 2012, 15, 388-393.

9 D. A. Shipp, Polym. Rev., 2011, 51, 99-103.

10 G. Moad, E. Rizzardo and S. H. Thang, Aust. J. Chem., 2012, 65, 985.

11 J. Chiefari, Y. K. Chong, F. Ercole, J. Krstina, J. Jeffery, T. P. T. Le, R. T. A. Mayadunne, G. F. Meijs, C. L. Moad, G. Moad, E. Rizzardo and S. H. Thang, Macromolecules, 1998, 31, 5559-5562.

12 M. Ahmed and R. Narain, Prog. Polym. Sci., 2013, 38, 767790.

13 G. P. Tang, J. M. Zeng, S. J. Gao, Y. X. Ma, L. Shi, Y. Li, H.-P. Too and S. Wang, Biomaterials, 2003, 24, 2351-2362.

14 Y. Chen, Y. Li, J. Gao, Z. Cao, Q. Jiang, J. Liu and Z. Jiang, ACS Appl. Mater. Interfaces, 2016, 8, 490-501.

15 K. Knop, R. Hoogenboom, D. Fischer and U. S. Schubert, Angew. Chem., Int. Ed., 2010, 49, 6288-6308.

16 U. Rungsardthong, M. Deshpande, L. Bailey, M. Vamvakaki, S. P. Armes, M. C. Garnett and S. Stolnik, J. Controlled Release, 2001, 73, 359-380.

17 W. Wu, W. Wang and J. Li, Prog. Polym. Sci., 2015, 46, $55-85$.
18 N. Hadjichristidis, J. Polym. Sci., Part A: Polym. Chem., 1999, 37, 857-871.

19 J. M. Ren, T. G. McKenzie, Q. Fu, E. H. H. Wong, J. Xu, Z. An, S. Shanmugam, T. P. Davis, C. Boyer and G. G. Qiao, Chem. Rev., 2016, 116, 6743-6836.

20 T. K. Georgiou, Polym. Int., 2014, 63, 1130-1133.

21 X. Liao, G. Walden, N. D. Falcon, S. Donell, M. J. Raxworthy, M. Wormstone, G. P. Riley and A. Saeed, Eur. Polym. J., 2017, 87, 458-467.

22 F. Dai, P. Sun, Y. Liu and W. Liu, Biomaterials, 2010, 31, 559-569.

23 T. K. Georgiou, M. Vamvakaki, C. S. Patrickios, E. N. Yamasaki and L. A. Phylactou, Biomacromolecules, 2004, 5, 2221-2229.

24 D. Fischer, T. Bieber, Y. Li, H. P. Elsässer and T. Kissel, Pharm. Res., 1999, 16, 1273-1279.

25 Y.-Y. Yang, X. Wang, Y. Hu, H. Hu, D.-C. Wu and F.-J. Xu, ACS Appl. Mater. Interfaces, 2014, 6, 1044-1052.

26 E. Themistou and C. S. Patrickios, Macromol. Chem. Phys., 2008, 209, 1021-1028.

27 A. Blencowe, J. F. Tan, T. K. Goh and G. G. Qiao, Polymer, 2009, 50, 5-32.

28 H. Y. Cho, A. Srinivasan, J. Hong, E. Hsu, S. Liu, A. Shrivats, D. Kwak, A. K. Bohaty, H. Paik, J. O. Hollinger and K. Matyjaszewski, Biomacromolecules, 2011, 12, 3478-3486.

29 E. Themistou and C. S. Patrickios, J. Polym. Sci., Part A: Polym. Chem., 2009, 47, 5853-5870.

30 Y.-Y. Yang, H. Hu, X. Wang, F. Yang, H. Shen, F.-J. Xu and D.-C. Wu, ACS Appl. Mater. Interfaces, 2015, 7, 12238-12248.

31 X. Wei, P. A. Gunatillake, G. Moad, E. Rizzardo, J. Rosselgong, W. Yang and S. H. Thang, Sci. China: Chem., 2014, 57, 995-1001.

32 E. Themistou and C. S. Patrickios, Macromolecules, 2006, 39, 73-80.

33 E. Themistou and C. S. Patrickios, Macromolecules, 2004, 37, 6734-6743.

34 E. Themistou and C. S. Patrickios, Macromolecules, 2007, 40, 5231-5234.

35 X. Wei, G. Moad, B. W. Muir, E. Rizzardo, J. Rosselgong, W. Yang and S. H. Thang, Macromol. Rapid Commun., 2014, 35, 840-845.

36 E. Themistou and C. S. Patrickios, Eur. Polym. J., 2007, 43, 84-92.

37 C. Boyer, M. Whittaker and T. P. Davis, J. Polym. Sci., Part A: Polym. Chem., 2011, 49, 5245-5256.

38 J. A. Syrett, D. M. Haddleton, M. R. Whittaker, T. P. Davis and C. Boyer, Chem. Commun., 2011, 47, 1449-1451.

39 L. Zhang and Y. Chen, Polymer, 2006, 47, 5259-5266.

40 F. J. Xu, Z. X. Zhang, Y. Ping, J. Li, E. T. Kang and K. G. Neoh, Biomacromolecules, 2009, 10, 285-293.

41 T. Terashima, S. Nishioka, Y. Koda, M. Takenaka and M. Sawamoto, J. Am. Chem. Soc., 2014, 136, 10254-10257.

42 B. Mendrek, Ł. Sieroń, I. Żymełka-Miara, P. Binkiewicz, M. Libera, M. Smet, B. Trzebicka, A. L. Sieroń, A. Kowalczuk and A. Dworak, Biomacromolecules, 2015, 16, 3275-3285. 
43 H. Y. Cho, S. E. Averick, E. Paredes, K. Wegner, A. Averick, S. Jurga, S. R. Das and K. Matyjaszewski, Biomacromolecules, 2013, 14, 1262-1267.

44 X. J. Loh and Y.-L. Wu, Chem. Commun., 2015, 51, 1081510818.

45 Y. Y. Durmaz, Y.-L. Lin and M. E. H. ElSayed, Adv. Funct. Mater., 2013, 23, 3885-3895.

46 C. Boyer, J. Teo, P. Phillips, R. B. Erlich, S. Sagnella, G. Sharbeen, T. Dwarte, H. T. T. Duong, D. Goldstein, T. P. Davis, M. Kavallaris and J. McCarroll, Mol. Pharm., 2013, 10, 2435-2444.

47 K. M. Xiu, J. J. Yang, N. N. Zhao, J. S. Li and F. J. Xu, Acta Biomater., 2013, 9, 4726-4733.

48 A. Zheng, Y. Xue, D. Wei, Y. Guan and H. Xiao, Mater. Sci. Eng., C, 2013, 33, 519-526.

49 K. S. Pafiti, N. P. Mastroyiannopoulos, L. A. Phylactou and C. S. Patrickios, Biomacromolecules, 2011, 12, 1468-1479.

50 T. K. Georgiou, L. A. Phylactou and C. S. Patrickios, Biomacromolecules, 2006, 7, 3505-3512.

51 A. M. Alhoranta, J. K. Lehtinen, A. O. Urtti, S. J. Butcher, V. O. Aseyev and H. J. Tenhu, Biomacromolecules, 2011, 12, 3213-3222.

52 B. Mendrek, Ł. Sieroń, M. Libera, M. Smet, B. Trzebicka, A. L. Sieroń, A. Dworak and A. Kowalczuk, Polymer, 2014, 55, 4551-4562.

53 A. Schallon, V. Jérôme, A. Walther, C. V. Synatschke, A. H. E. Müller and R. Freitag, React. Funct. Polym., 2010, 70, 1-10.

54 J. Teo, J. A. McCarroll, C. Boyer, J. Youkhana, S. M. Sagnella, H. T. T. Duong, J. Liu, G. Sharbeen, D. Goldstein, T. P. Davis, M. Kavallaris and P. A. Phillips, Biomacromolecules, 2016, 17, 2337-2351.

55 T. K. Georgiou, M. Vamvakaki, L. A. Phylactou and C. S. Patrickios, Biomacromolecules, 2005, 6, 2990-2997.

56 K. S. Pafiti, C. S. Patrickios, T. K. Georgiou, E. N. Yamasaki, N. P. Mastroyiannopoulos and L. A. Phylactou, Eur. Polym. J., 2012, 48, 1422-1430.

57 D. Prat, A. Wells, J. Hayler, H. Sneddon, C. R. McElroy, S. Abou-Shehada and P. J. Dunn, Green Chem., 2016, 18, 288-296.

58 J. Ferreira, J. Syrett, M. Whittaker, D. Haddleton, T. P. Davis and C. Boyer, Polym. Chem., 2011, 2, 1671.

59 Q. Qiu, G. Liu and Z. An, Chem. Commun., 2011, 47, 12685.

60 X. Cao, C. Zhang, S. Wu and Z. An, Polym. Chem., 2014, 5, 4277.

61 X. Shi, M. Miao and Z. An, Polym. Chem., 2013, 4, 1950.

62 Q. Chen, X. Cao, H. Liu, W. Zhou, L. Qin and Z. An, Polym. Chem., 2013, 4, 4092.

63 X. Shi, W. Zhou, Q. Qiu and Z. An, Chem. Commun., 2012, 48, 7389.
64 K. Wang, H. Peng, K. J. Thurecht, S. Puttick and A. K. Whittaker, Polym. Chem., 2014, 5, 1760-1771.

65 B. S. Tucker, S. G. Getchell, M. R. Hill and B. S. Sumerlin, Polym. Chem., 2015, 6, 4258-4263.

66 Q. Chen, F. Han, C. Lin, X. Wen and P. Zhao, Polymer, 2018, 146, 378-385.

67 J.-F. Lutz, J. Polym. Sci., Part A: Polym. Chem., 2008, 46, 3459-3470.

68 J. Da Silva, S. Jesus, N. Bernardi, M. Colaço and O. Borges, Front. Bioeng. Biotechnol., 2019, 7, 137.

69 R. P. Singh and P. Ramarao, Toxicol. Sci., 2013, 136, 131143.

70 P. Thomas and T. G. Smart, J. Pharmacol. Toxicol. Methods, 2005, 51, 187-200.

71 T. Vink, M. Oudshoorn-Dickmann, M. Roza, J.-J. Reitsma and R. N. de Jong, Methods, 2014, 65, 5-10.

72 C. D. Walkey, J. B. Olsen, H. Guo, A. Emili and W. C. W. Chan, J. Am. Chem. Soc., 2012, 134, 2139-2147.

73 Y.-P. Li, Y.-Y. Pei, X.-Y. Zhang, Z.-H. Gu, Z.-H. Zhou, W.-F. Yuan, J.-J. Zhou, J.-H. Zhu and X.-J. Gao, J. Controlled Release, 2001, 71, 203-211.

74 C.-W. Lo, Y. Chang, J.-L. Lee, W.-B. Tsai and W.-S. Chen, PLoS One, 2014, 9, e97627.

75 D. W. Pack, A. S. Hoffman, S. Pun and P. S. Stayton, Nat. Rev. Drug Discovery, 2005, 4, 581-593.

76 B. D. Monnery, M. Wright, R. Cavill, R. Hoogenboom, S. Shaunak, J. H. G. Steinke and M. Thanou, Int. J. Pharm., 2017, 521, 249-258.

77 E. Themistou, A. Kanari and C. S. Patrickios, J. Polym. Sci., Part A: Polym. Chem., 2007, 45, 5811-5823.

78 D. Kafouris, E. Themistou and C. S. Patrickios, Chem. Mater., 2006, 18, 85-93.

79 D. Das, S. Srinivasan, F. D. Brown, F. Y. Su, A. L. Burrell, J. M. Kollman, A. Postma, D. M. Ratner, P. S. Stayton and A. J. Convertine, Polym. Chem., 2018, 9, 2134-2146.

80 R. Banerjee, S. Parida, C. Maiti, M. Mandal and D. Dhara, RSC Adv., 2015, 5, 83565-83575.

81 M. Kawamura, A. Kanazawa, S. Kanaoka and S. Aoshima, Polym. Chem., 2015, 6, 4102-4108.

$82 \mathrm{~J} . \mathrm{Hu}, \mathrm{J}$. He, M. Zhang and P. Ni, Polym. Chem., 2015, 6, 1553-1566.

83 L. Parhamifar, A. K. Larsen, A. C. Hunter, T. L. Andresen and S. M. Moghimi, Soft Matter, 2010, 6, 4001.

84 C. S. Hughes, L. M. Colhoun, B. K. Bains, J. D. Kilgour, R. E. Burden, J. F. Burrows, E. C. Lavelle, B. F. Gilmore and C. J. Scott, Part. Fibre Toxicol., 2015, 13, 19.

85 P. Boya and G. Kroemer, Oncogene, 2008, 27, 64346451.

86 W. Song, L. Popp, J. Yang, A. Kumar, V. S. Gangoli and L. Segatori, J. Nanobiotechnol., 2015, 13, 87. 